\title{
The Effect of Lycopene Preexposure on UV-B-Irradiated Human Keratinocytes
}

\author{
Andreia Ascenso, ${ }^{1,2}$ Tiago Pedrosa, ${ }^{2}$ Sónia Pinho, ${ }^{2}$ Francisco Pinho, ${ }^{2}$ \\ José Miguel P. Ferreira de Oliveira, ${ }^{2}$ Helena Cabral Marques, ${ }^{1}$ Helena Oliveira, ${ }^{2}$ \\ Sandra Simões, ${ }^{1}$ and Conceição Santos ${ }^{2}$ \\ ${ }^{1}$ Instituto de Investigação do Medicamento (iMed.ULisboa), Faculdade de Farmácia, Universidade de Lisboa, \\ Avenida Professor Gama Pinto, 1649-003 Lisboa, Portugal \\ ${ }^{2}$ Departamento de Biologia, Laboratório de Biotecnologia e Citómica, CESAM, Universidade de Aveiro, \\ Campus Universitário de Santiago, 3810-193 Aveiro, Portugal
}

Correspondence should be addressed to Andreia Ascenso; andreiaascenso@ff.ul.pt

Received 20 May 2015; Revised 3 July 2015; Accepted 6 July 2015

Academic Editor: Luciano Saso

Copyright (C) 2016 Andreia Ascenso et al. This is an open access article distributed under the Creative Commons Attribution License, which permits unrestricted use, distribution, and reproduction in any medium, provided the original work is properly cited.

Lycopene has been reported as the antioxidant most quickly depleted in skin upon UV irradiation, and thus it might play a protective role. Our goal was to investigate the effects of preexposure to lycopene on UV-B-irradiated skin cells. Cells were exposed for $24 \mathrm{~h}$ to $10 \mathrm{M}$ lycopene, and subsequently irradiated and left to recover for another $24 \mathrm{~h}$ period. Thereafter, several parameters were analyzed by FCM and RT-PCR: genotoxicity/clastogenicity by assessing the cell cycle distribution; apoptosis by performing the Annexin- $\mathrm{V}$ assay and analyzing gene expression of apoptosis biomarkers; and oxidative stress by ROS quantification. Lycopene did not significantly affect the profile of apoptotic, necrotic and viable cells in nonirradiated cells neither showed cytostatic effects. However, irradiated cells previously treated with lycopene showed an increase in both dead and viable subpopulations compared to nonexposed irradiated cells. In irradiated cells, lycopene preexposure resulted in overexpression of $B A X$ gene compared to nonexposed irradiated cells. This was accompanied by a cell cycle delay at S-phase transition and consequent decrease of cells in G0/G1 phase. Thus, lycopene seems to play a corrective role in irradiated cells depending on the level of photodamage. Thus, our findings may have implications for the management of skin cancer.

\section{Introduction}

Human skin is constantly exposed to the UV irradiation that may induce a number of pathobiological cellular changes. Through lipid peroxidation, protein cross-linking, and DNA damage, UV-A and UV-B radiation (UVR) can cause photoaging and photocarcinogenesis [1-3]. Skin has a variety of enzymatic and small molecular antioxidants that can inhibit oxidative damage. However, the excessive ROS production often exceeds the skin antioxidant ability [4]. In this regard, emphasis on developing novel preventive and therapeutic strategies based on phytocompounds capable of ameliorating the adverse effects of ROS has become an important area of research. Moreover, primary prevention approaches of skin cancer proved to be inadequate in lowering the incidence of this type of cancer, emphasizing the need to develop novel skin cancer chemopreventive agents. Among the vast number of photochemoprotective agents, botanical antioxidants have given promising results [4]. Two types of chemopreventive agents could be useful for the management of skin cancer. Primarily, the agents that could inhibit the damage caused by UVR may prevent the formation of initiated cells (cells with cancerous potential). Secondly, the agents that could eliminate the initiated cells may reduce the risk of skin cancer $[5]$.

Lycopene is a powerful antioxidant both in vitro and in vivo against the oxidation of proteins, lipids, and DNA, and it has been identified as one of the most potent scavengers of 
singlet species of oxygen free radicals - the highest among the carotenoids $[6,7]$. At low oxygen tension, it can also scavenge peroxyl radicals, inhibiting the process of lipid peroxidation [8]. Lycopene was reported as the most quickly depleted antioxidant in skin upon exposure to solar radiation [9] and might play a role of protection against UVR. Recent research has been developed to assess if lycopene has potential for prevention of skin cancer. In fact, lycopene has been shown to inhibit proliferation of several types of cancer cells through different mechanisms in in vitro systems $[10,11]$. Chemopreventive antioxidants are mostly studied for their role as radical scavengers, but this preventive role can be complemented by a corrective activity as selective inducers of apoptosis in transformed cells [12]. Moreover, RibayaMercado et al. [9] suggested a role of lycopene in mitigating photooxidative damage in tissues.

Keratinocytes are the predominant cell type (95\%) in the epidermis, the outermost layer of the skin [13]. Considering that the principal site of action of UV-B is the epidermis layer [14], keratinocytes might be more susceptible to UVB-induced apoptosis than fibroblasts which are located in dermis layer (reached by UV-A) [15]. However, keratinocytes may be more UV-B resistant in terms of their proliferative ability as measured by colony survival assays and have greater ability for UV-DNA repair [15].

To date, most of the studies on the therapeutic potential of lycopene have been performed in vivo [16, 17]. These studies may be obscured by the complexity of biological system models. In vitro conditions may circumvent some of these contingencies and complement in vivo data within the 3Rs perspective (Refine, Replace, and Reduce). Despite the lower complexity of in vitro systems, the study of cellular photoprotection by antioxidants could be challenging because of the high chemical instability (especially to air and light) and strong lipophilicity of many antioxidant molecules such as lycopene. According to Zefferino et al. [11] in vitro experiments may occasionally produce inconsistent results due to lycopene's poor solubility in cell culture media [18]. In fact, lycopene is very hydrophobic $(\log P \approx 15)$ and is usually solubilized in organic solvents such as tetrahydrofuran (THF). However, an uncontrolled precipitation process may occur upon addition to aqueous media, besides the high toxicity associated with these solvents. The solubility and uptake of these large crystals in the cells are quite limited and there is almost no protection against chemical degradation [19]. Alternative ways of delivering lipid-soluble compounds include micelles, microemulsions, nanoparticles, water-dispersible beadlets, artificial liposomes, enriched bovine serum, or other formulations, each of which has an influence on the cellular uptake and compounds stability [18, 20-23]. According to Palozza et al., niosomes provide a suitable, safe, and low-cost vehicle for $\beta$-carotene in cell culture [24]. Lipid-based delivery systems also show UVblocking effects dependent on lipid composition and the particle size (the smaller the particle size, the higher the sunscreen activity). Lipid matrices can act as sunscreen carriers and increase the sun protection factor obtained after topical application of $\mathrm{UV}$ absorbers $\left(\mathrm{BaSO}_{4}, \mathrm{SrCO}_{3}\right.$, and $\mathrm{TiO}_{2}$ ) incorporated within these carriers because they provide a fixation medium for these pigments $[25,26]$. However, the UV-blocking effect of the vehicle is not desired in this case, besides the difficulties of using these hydrophobic systems for cell culture studies.

The main limitations of different vehicles used for lycopene cell delivery are summarized on Table 1. Each vehicle provides specific advantages but also offers some limitations such as cytotoxicity, poor solubility, and crystallization in the cell medium [27].

In addition, the half-life of free lycopene in solution at $37^{\circ} \mathrm{C}$ is less than few hours. Thus, until an efficient method of solubilizing lycopene in aqueous buffers and cell culture media is developed, in vitro studies on the effects of lycopene on living cells will continue to show considerable variation between laboratories and cell lines and should be interpreted with caution [39].

Pfitzner et al. [18] have demonstrated that methyl- $\beta-C D$ $(\mathrm{M}-\beta-\mathrm{CD})$ was an improved vehicle for the investigation of carotenoids and other lipophilic compounds in in vitro test systems, compared to organic solvents. Carotenoids-M- $\beta$ CD complex was superior concerning biological availability, missing cytotoxicity and presenting excellent stability when compared to other application forms such as organic solvents, mixed micelles, liposomes, or beadlets. At least, the solubilization with $\mathrm{M}-\beta$-CD was easily and reproducibly achievable under routine laboratory conditions.

According to these literature references [18, 27] and preformulations studies, we decided to use another similar CD derivative, dimethyl- $\beta$-CD (DM- $\beta-C D)$, to solubilize and stabilize lycopene for cell exposure experiments. Depending on the formulation and exposure conditions, lycopene has been shown to prevent cellular damage or otherwise to sensitize damaged cells leading to increased cell death. We aimed to study the effects of lycopene as sensitizer and inducer of cell death in UV-B damaged keratinocytes. Our hypothesis was that cells preexposed to lycopene would be more sensitized to death, in case of subsequent irreversible damage by UVB. For this, the nontumorigenic keratinocyte cell line HaCaT [40] was used. HaCaT cells were preexposed to lycopene for sensitization and subsequently exposed to damaging UV-B irradiation. The effect of lycopene preexposure was analyzed by assays focused on cytotoxicity, genotoxicity, oxidative stress, and apoptosis.

\section{Materials and Methods}

2.1. Preparation of Lycopene Complex Solution. In order to avoid the use of organic solvents, lycopene (Extrasynthese, Genay, France, with a purity $\geq 98 \%$, UV assay) was solubilized by complexation with dimethyl-beta-cyclodextrin (CD, degree of substitution: 1.8) which was a generous gift from Wacker (Stuttgart, Germany). Aqueous solutions of lycopene complexed with CD (1:4 molar ratio) were prepared under aseptic conditions within concentrations of $0,5,10,15$, and $20 \mu \mathrm{M}$ from a concentrated lycopene solution previously stirred with $\mathrm{CD}$ during approximately $48 \mathrm{~h}$ and sonicated $30 \mathrm{~min}$ (before use), always protected from light and air. Lycopene solutions were always freshly prepared under light and air protection and stored at $-20^{\circ} \mathrm{C}$ (except the pure 
TABLE 1: Limitations of different vehicles used for lycopene cell delivery (adapted from Lin et al. [27]).

\begin{tabular}{llll}
\hline Vehicle & Limitations & References \\
\hline Tetrahydrofuran (THF) & Rapid oxidation in media, leading to lycopene instability and cytotoxicity & {$[17,20,22,28-32]$} \\
\hline Dimethyl sulfoxide (DMSO) & Reduced solvent capacity for carotenoids $(0.01 \mathrm{mg} / \mathrm{mL}$ for lycopene) & {$[20,33-35]$} \\
\hline Tween & Possible oxidation of carotenoids, after solvent drying and filtration & {$[31]$} \\
\hline Micelles & Low carotenoid stabilization and increased cytotoxicity & {$[20,27,36]$} \\
\hline Water-dispersible beadlets & $\begin{array}{l}\text { Low toxicity, but also low cellular uptake, depends on chemicals that interfere in } \\
\text { assays (e.g., hexane and chloroform) }\end{array}$ & {$[29,37,38]$} \\
\hline
\end{tabular}

lycopene standard, stored at $-70^{\circ} \mathrm{C}$ ). The osmolarity of the sample containing the highest lycopene concentration was determined using an automatic osmometer (Knauer, Berlin, Germany).

When nonspecified, all higher grade reagents were from Sigma-Aldrich (St. Louis, MO, USA). All solutions were prepared using ultrapure water obtained in a MILLI-Q System from Millipore (Billerica, MA, USA).

\subsection{Human Immortalized Keratinocytes (HaCaT) Cell Line.} The HaCaT cell line was obtained from Cell Lines Services (CLS) (Eppelheim, Germany). Handling and culture of these cells were adapted to meet CLS protocol procedures. Cells were aseptically grown in Dulbecco's modified Eagle's medium (DMEM, no HEPES, no Pyruvate), high glucose, supplemented with $10 \%$ fetal bovine serum (FBS), 2 mM Lglutamine, $1 \%$ penicillin-streptomycin $(10,000 \mathrm{U} / \mathrm{mL})$, and $1 \%$ fungizone $(250 \mathrm{U} / \mathrm{mL}$ ) (Gibco, Life Technologies, Grand Island, NY, USA) at $37^{\circ} \mathrm{C}$ in a humidified atmosphere with $5 \% \mathrm{CO}_{2}$.

2.3. HaCaT Cell Growth and Confluence under Normal Culture Conditions. The standard cell growth conditions were established after the analysis of $\mathrm{HaCaT}$ growth curves. $\mathrm{HaCaT}$ cells were seeded in a 6-well cluster plate $(300,000$ cells/well). Cell confluence and morphology were daily observed under microscope. After 3 days, cells were harvested by trypsinization according to CLS procedure. Briefly, the culture was rinsed twice with phosphate-buffered saline solution (PBS) without $\mathrm{Ca}^{2+}$ or $\mathrm{Mg}^{2+}$ (Gibco, Life Technologies, Grand Island, NY, USA) and then with PBS containing 0.05\% EDTA to remove desmosomes and incubated at $37^{\circ} \mathrm{C}$ about 5$10 \mathrm{~min}$. After this, EDTA solution was replaced by a $1: 1$ mixture of EDTA/trypsin-solution (final concentrations of $0.025 \%$ and $0.05 \%$, resp.). The trypsinization was achieved after incubating at $37^{\circ} \mathrm{C}$ for $15-20 \mathrm{~min}$. At this time, a double volume of complete culture medium (with FBS) was added to stop the detaching process and cells were suspended with stronger shaking, followed by the use of a syringe $(21 \mathrm{G})$ because of its mechanical resistance. All cell manipulation and growth and subsequent exposure conditions were performed under strict aseptic procedures.

Cell density was calculated by counting with a hemocytometer (Neubauer Improved) under a phase-contrast microscope Nikon Eclipse 80i (Coyoacán, Mexico).

\subsection{Selection of Exposure Conditions}

2.4.1. Selection of UV-Irradiation Dose. Ten UV-B lamps (Sankyo Denki G8T5E, Kanagawa, Japan) with a peak emission at $312 \mathrm{~nm}$ were used as the UV-B source. The UV$\mathrm{B}$ irradiation was measured with a VLX 312 radiometer equipped with a UV-B sensor (Vilber Lourmat, Marne-laVallée Cedex, France). Around 7,000 cells/well were cultured in a 96-well cluster plate with complete medium. Twentyfour hours after, the cells were exposed to five different UV$\mathrm{B}$ irradiation doses [based on related literature [41-45] of $\sim 75,150,200,225$, and $325 \mathrm{~mJ} / \mathrm{cm}^{2}$ (moderate-high to veryhigh dose)]. In order to prevent UV quenching, prior to irradiation, the cell culture medium was replaced by the same volume of PBS after two washing steps with PBS. After UV-B irradiation, cells were fed with fresh growth medium and incubated for $24 \mathrm{~h}$. Cell metabolic activity was assessed as described below by the MTT assay (often used as viability method) in order to choose just one UV-B dose. Nonirradiated samples were used as negative control.

2.4.2. Selection of Complexed Lycopene Dose. From previous cell viability results of $\mathrm{HaCaT}$ cells exposed to UV-B irradiation, new exposure conditions were tested with different LycCD concentrations and a fixed UV-B irradiation dose. Briefly, cells were seeded and grown in DMEM (Dulbecco's modified Eagle's medium) supplemented with $10 \%$ FBS, $1 \%$ penicillinstreptomycin, and $1 \%$ fungizone, for $24 \mathrm{~h}$, and then DMEM medium was replaced with $\alpha$-MEM without nucleosides (Gibco, Life Technologies) with identical supplementation, containing complexed lycopene solutions $(0,5,10,15$, and $20 \mu \mathrm{M})$. Cells were exposed for $24 \mathrm{~h}$, and after UV-B irradiation $\left(225 \mathrm{~mJ} / \mathrm{cm}^{2}\right) \mathrm{HaCaT}$ irradiated cells were incubated under standard culture conditions for a final $24 \mathrm{~h}$ period. The metabolic activity of cell culture was analyzed by MTT assay in order to choose just one lycopene dose for the subsequent analyses (Figure 1).

Briefly, for further experiments, $\mathrm{HaCaT}$ cells were seeded in a 6-well cluster plate (150,000-300,000 cells/2 mL well) and incubated $24 \mathrm{~h}$ under the same culture conditions, as mentioned above. After this period, the cells were exposed to complexed lycopene $(10 \mu \mathrm{M})$ for $24 \mathrm{~h}$ in order to achieve its cellular internalization and a higher cell confluence, and after UV-B irradiation $\left(225 \mathrm{~mJ} / \mathrm{cm}^{2}\right)$ cells were allowed to grow under standard culture conditions for another $24 \mathrm{~h}$ to enable the occurrence of cellular repair mechanisms. 

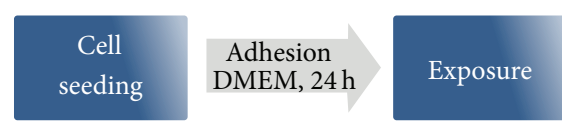

$10 \mu \mathrm{M}$ Lyc-CD

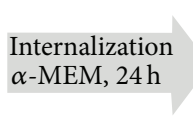

(1) $24 \mathrm{~h}$

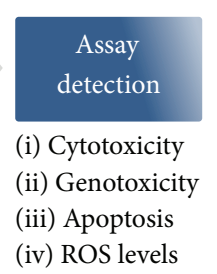

FIGURE 1: Culture conditions and experimental setting for the study of HaCaT cells exposed to complexed lycopene (Lyc-CD) and UV-B irradiation.

2.5. MTT Assay. Cell metabolic activity was assessed by the MTT (Sigma-Aldrich, St. Louis, MO, USA) assay, which is often used to roughly estimate culture's viability/proliferation characteristics. Cells were seeded at a density of 7,000 cells/well in a 96-well cluster plate. After complexed lycopene exposure, UV-B irradiation, and $24 / \mathrm{h}$ recovery the MTT assay was performed as previously described [46]. The optical density of reduced MTT was measured at $570 \mathrm{~nm}$ by spectroscopy on an automatic microtiter plate reader (Synergy HT Multi-Mode from BioTeK Instruments Inc., Winooski, VT, USA) and cell metabolic activity $(\mathrm{MA} \approx$ viability or proliferation characteristics) was calculated according to

$$
\begin{aligned}
& \text { Cell MA }(\%) \\
& \begin{aligned}
= & \frac{\left(\text { Abs } 570 \mathrm{~nm}_{\text {sample }}-\text { Abs } 570 \mathrm{~nm}_{\mathrm{DMSO}}\right)}{\left(\text { Abs } 570 \mathrm{~nm}_{\text {negative control }}-\text { Abs } 570 \mathrm{~nm}_{\mathrm{DMSO}}\right)} \\
& \times 100 .
\end{aligned}
\end{aligned}
$$

Besides the negative control (nonexposed and nonirradiated cells), the assays results were also compared to CD aqueous solutions (vehicle control) with the same dilution factors used for complexed lycopene samples.

2.6. Cell Cycle Analysis by Flow Cytometry. After complexed lycopene exposure and UV-B irradiation as described before, the cells were harvested with Accutase and centrifuged at $1157 \mathrm{~g}$ for $5 \mathrm{~min}$ at $4^{\circ} \mathrm{C}$. The supernatant was removed and the cells were washed in PBS and suspended in $1 \mathrm{~mL}$ of $85 \%$ ethanol at $4^{\circ} \mathrm{C}$ and kept at $-20^{\circ} \mathrm{C}$ until analysis. After that, the cells were centrifuged twice at $1157 \mathrm{~g}$ for $5 \mathrm{~min}$ at $4^{\circ} \mathrm{C}$ and suspended in $800 \mu \mathrm{L}$ PBS and vortexed. Cell cycle analysis was done as previously described [46]. Briefly, samples were filtered on a nylon mesh $(50 \mu \mathrm{m}$ pore size) to the analysis tubes. Propidium iodide (PI), a DNA intercalating fluorochrome, and RNase were added to the samples $(50 \mu \mathrm{L}$ each one) and vortexed. The mixture was incubated $20 \mathrm{~min}$ at room temperature and then analyzed by flow cytometry (FCM) using a Coulter EPICS XL flow cytometer. The instrument was equipped with an air-cooled argon-ion laser tuned at $15 \mathrm{~mW}$ and operating at $488 \mathrm{~nm}$ for excitation. Data was acquired using the SYSTEM II (v. 2.5) software. Integral fluorescence together with fluorescence pulse height and width emitted from nuclei was collected through a 645 dichroic long-pass filter and a 620 band-pass filter and converted on 1024 ADC channels. Prior to analysis the amplification was adjusted so that the peak corresponding to G0/G1 was positioned at channel 200. This setting was kept constant. The results were obtained in the form of three graphics: linear fluorescence light intensity (FL), forward angle light scatter (FS) versus side angle light scatter (SS), and FL pulse integral versus FL pulse height. This last cytogram was used to eliminate partial nuclei and other debris, nuclei with associated cytoplasm and doublets (these events have a higher pulse area but the same pulse height as single nuclei). Cell cycle analysis was performed using the FlowJo software (Tree Star Inc., Ashland, Oregon, USA) applying the DeanJett Model. Results were expressed as \% of nuclei in G0/G1, S, and G2 phases of the cell cycle. The \% of nuclei in Sub-G0/G1 indicative of DNA fragmentation was also computed.

2.7. Analysis of Apoptosis by Flow Cytometry. Early and late apoptosis were investigated by FCM using Annexin V-FITC Apoptosis Detection Kit from BD Pharmingen (Franklin Lakes, NJ, USA), as previously described [47]. Briefly, after complexed lycopene exposure and UV-B irradiation as described before, the cells were gently harvested with Accutase (PAA Laboratories, Pasching, Austria) and washed twice in cold PBS $(1 \mathrm{~mL})$. Finally, Annexin V-FITC and PI, $5 \mu \mathrm{L}$ of each, were added to $100 \mu \mathrm{L}$ of cell suspension $\left(10^{5}\right.$ cells $/ \mathrm{mL}$ ) in binding buffer. Samples were left in the dark for $15 \mathrm{~min}$ and $400 \mu \mathrm{L}$ of binding buffer was added. Samples were analyzed by FCM using a Coulter EPICS XL flow cytometer (Coulter Electronics, Hialeah, Florida, USA). Data were acquired using the SYSTEM II (v. 2.5) software. The cytogram of FITC fluorescence in log scale versus PI fluorescence in log scale allows the identification of nonapoptotic cells (Annexin V-FITC negative, PI negative), exclusively early apoptotic cells (Annexin V-FITC positive, PI negative), predominantly late apoptotic cells (Annexin V-FITC positive, PI positive), and predominantly necrotic or dead cells (Annexin V-FITC negative, PI positive). FCM data were analyzed by FlowJo software (Tree Star Inc., Ashland, OR).

\subsection{RNA Extraction and qPCR Analysis of Apoptosis Regulating Genes}

2.8.1. Total RNA Extraction. At least $1 \times 10^{5} \mathrm{HaCaT}$ cells were rinsed twice with sterile PBS after removal of culture medium. After rinsing, cells were lysed in $1 \mathrm{~mL}$ TRIzol reagent (Life Technologies, Saint Louis, MO, USA) and after $5 \mathrm{~min}$ room temperature incubation, $200 \mu \mathrm{L}$ chloroform was added to each sample, shaken on vortex for $10 \mathrm{~s}$, and incubated at room temperature for $2 \mathrm{~min}$. Phase separation was achieved by centrifugation at $12,000 \mathrm{~g}$ for $5 \mathrm{~min}$ at $4^{\circ} \mathrm{C}$ 
in Phase-Lock Gel Heavy tubes (5 Prime 3 Prime, Inc., Boulder, CO, USA). The aqueous phase was mixed with 1 volume $70 \%$ ethanol and RNA was further purified using RNeasy Mini Kit columns (Qiagen, Hilden, Germany) following the manufacturer's recommendations. The total RNA was quantified by spectrophotometry at 260-280 and 230$260 \mathrm{~nm}$ (Nanodrop Spectrophotometer ND-1000, Thermo Fisher Scientific, Wilmington, DE, USA).

2.8.2. cDNA Synthesis. $1 \mu \mathrm{g}$ total RNA was reverse-transcribed using the Omniscript RT Kit (Qiagen, Hilden, Germany) in a reaction mixture containing $1 \mu \mathrm{M}$ Oligo(dT)18 primer, $5 \mathrm{mM}$ dNTPs, reaction buffer, and RT enzyme according to the manufacturer's instructions. After the enzymatic reaction (incubation at $37^{\circ} \mathrm{C}$ for $1 \mathrm{~h}$ ), cDNA samples were prediluted in milliQ water $(1: 20)$.

2.8.3. Quantitative RT-PCR ( $q P C R)$. For qPCR, primers were used complementary to the genes coding for Bax, Bcl-2, caspase 3, and TRAIL proteins, respectively, BAX, BCL2, CASP3, and TNFSF10. SDHA (succinate dehydrogenase) was used as the reference gene. The target genes and corresponding oligonucleotide primer sequences $\left(5^{\prime}\right.$ to $\left.3^{\prime}\right)$ were as follows: BAX-F: GACGGCCTCCTCTCCTACTT; BAX-R: CAGCCCATCTTCTTCCAGAT; BCL2-F: GGA GGATTGTGGCCTTCTTT; BCL2-R: GCCGGTTCAGG TACTCAGTC; CASP3-F: GAACTGGACTGTGGCATT GA; CASP3-R: TGTCGGCATACTGTTTCAGC; TNFSF10F (TRAIL-F): CCTGCAGTCTCTCTGTGTGG; TNFSF10R (TRAIL-R): ACGGAGTTGCCACTTGACTT; SDHAF: CTGCAGAACCTGATGCTGTGT; SDHA-R: GGATGGGCTTGGAGTAATCG.

Primer design was performed using Primer3 [48] and primer specificity was confirmed using the In-Silico PCR UCSC Genome Browser [49]. The final individual qPCR reactions contained iTaq Universal SYBR Green Supermix (BioRad, Hercules, CA), $150 \mathrm{nM}$ of each primer, and 1: 4 (v/v) prediluted cDNA $(1: 20)$. Two qPCR technical replicates were performed per sample in the $\mathrm{iQ} 5$ Bio-Rad thermal cycler. The qPCR program included $1 \mathrm{~min}$ denaturation at $95^{\circ} \mathrm{C}$, followed by 60 cycles at $94^{\circ} \mathrm{C}$ for $5 \mathrm{~s}, 58^{\circ} \mathrm{C}$ for $15 \mathrm{~s}$, and $72^{\circ} \mathrm{C}$ for $15 \mathrm{~s}$. After qPCR, a melting temperature program was performed. Mean PCR efficiencies and cycle thresholds were determined from the fluorescence data using the algorithm Real-Time PCR Miner [50]. Relative gene expression of cell samples relative to SDHA was calculated using the Pfaffl method [51].

2.9. Reactive Oxygen Species (ROS) Quantification by Flow Cytometry. ROS $\left(\mathrm{O}_{2}{ }^{--}\right.$and $\left.{ }^{\circ} \mathrm{OH}\right)$ generation was assayed by FCM using the fluorescent probe 2,7-dichlorodihydrofluorescein diacetate $\left(\mathrm{H}_{2} \mathrm{DCF}-\mathrm{DA}\right)$, as described previously [47], which upon acetate cleavage is oxidized to fluorescent dichlorofluorescein (DCF) by hydrogen peroxide. After complexed lycopene exposure and UV-B irradiation as described before, the medium was replaced by serum-free $\alpha$-MEM containing $10 \mu \mathrm{M} \mathrm{H}_{2} \mathrm{DCF}-\mathrm{DA}$ for $30 \mathrm{~min}$, at $37^{\circ} \mathrm{C}$ in dark. Cells were washed with PBS, trypsinized with Accutase collected, and analyzed in a Coulter EPICS XL flow cytometer and ROS formation was estimated by the median fluorescence intensity (MFI) parameter using the FlowJo software.

2.10. Statistical Analysis. The results are reported as mean $\pm \mathrm{SD}$ of at least three replicates/treatment. In addition, at least three independent assays were performed for each analysis. For gene expression analysis, results are reported as mean \pm SE of at least three replicates from 2 independent assays. The results of all these experiments were statistically analyzed by Analysis of Variance (ANOVA with All Pairwise/Nonpairwise Multiple Comparison Procedures) using SigmaPlot 11.0 software. The differences were considered statistically significant when $P<0.05$.

\section{Results}

3.1. HaCaT Cell Growth and Confluence under Normal Culture Conditions. HaCaT cell growth and confluence under normal culture conditions until $120 \mathrm{~h}$ are represented on Figure 2(a). As it can be observed, the exponential phase extends until approximately $72 \mathrm{~h}$ and the full confluence can be maintained more than 1 week. The selected confluence for complexed lycopene exposure and UV irradiation in this experiment was attained at $24 \mathrm{~h}$ and $48 \mathrm{~h}$, respectively.

Under phase-contrast microscopy, the cells displayed typical intermediate phenotype of polygonal cells interspersed with giant often multinucleated cell and single morphology (Figure 2(b)).

3.2. Effect of UV-B Doses on Cell Metabolic Activity by MTT Assay. As theoretically expected, increasing UV-B dose resulted in decreased cell metabolic activity (Figure 3). UV$\mathrm{B}$ irradiation resulted in distinct morphological changes in $\mathrm{HaCaT}$ cells, as irradiated cells became round and detached from the surface of the plate.

According to MTT results, the UV-B condition tested that was near but above $50 \%$ viability was $225 \mathrm{~mJ} / \mathrm{cm}^{2}$. This UV-B dose was chosen as high UV-exposure condition to analyze the maximum range of effects and response to $\mathrm{UV}$ exposure.

Complexed lycopene (Lyc-CD) up to $15 \mu \mathrm{M}$ did not affect the metabolic activity of nonirradiated cells, and only $20 \mu \mathrm{M}$ Lyc-CD led to significant decrease in metabolic activity in these cells (Figure 4). At doses equal to or higher than $15 \mu \mathrm{M}$, complexed lycopene decreases the MA of irradiated cells $\left(225 \mathrm{~mJ} / \mathrm{cm}^{2}\right)$, compared to cells not preexposed to lycopene (Figure 4).

According to preliminary MTT assays, it was also observed that concentrations of Lyc-CD higher than $20 \mu \mathrm{M}$ induced a higher decrease in MA in irradiated cells (supplementary data in Supplementary Material available online at http://dx.doi.org/10.1155/2016/8214631).

According to these results, we decided to choose an intermediate complexed lycopene concentration $(10 \mu \mathrm{M})$ whose effects have been previously established in other cell lines [5254]. At this lycopene concentration, the cell metabolic activity was higher than $50 \%$ and was not significantly different from 


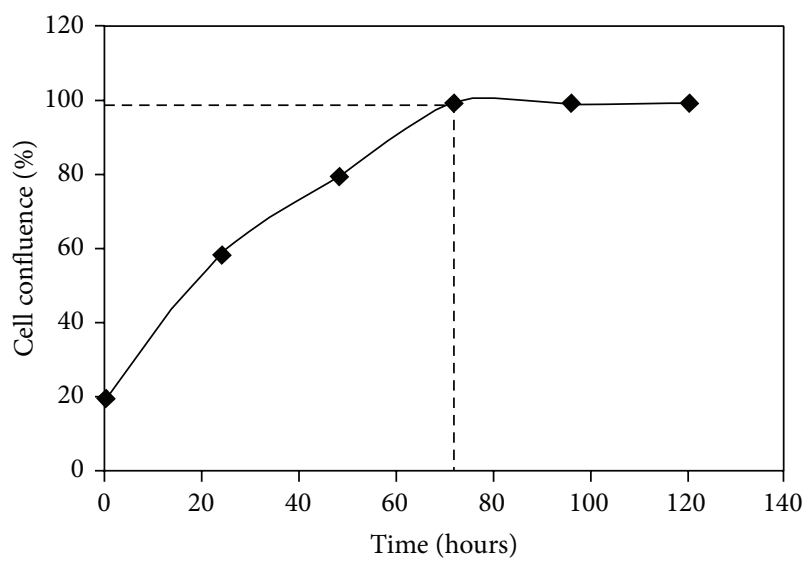

(a)

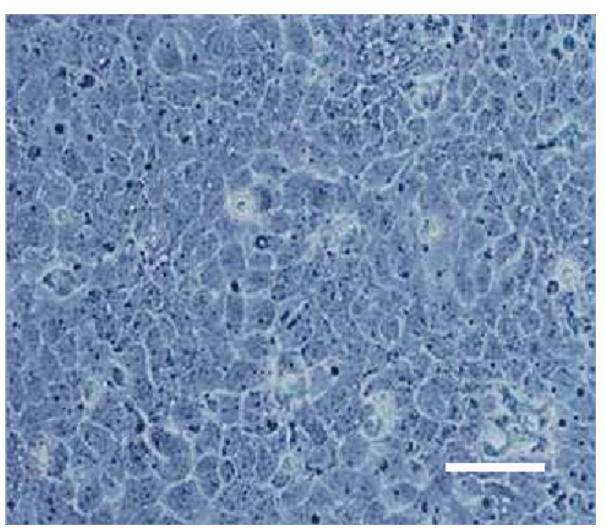

(b)

Figure 2: (a) HaCaT cells growth and confluence curves under normal culture conditions for $120 \mathrm{~h}$. (b) HaCaT cells observed by phasecontrast microscope (100x magnification), scale bar: $20 \mu \mathrm{m}$.

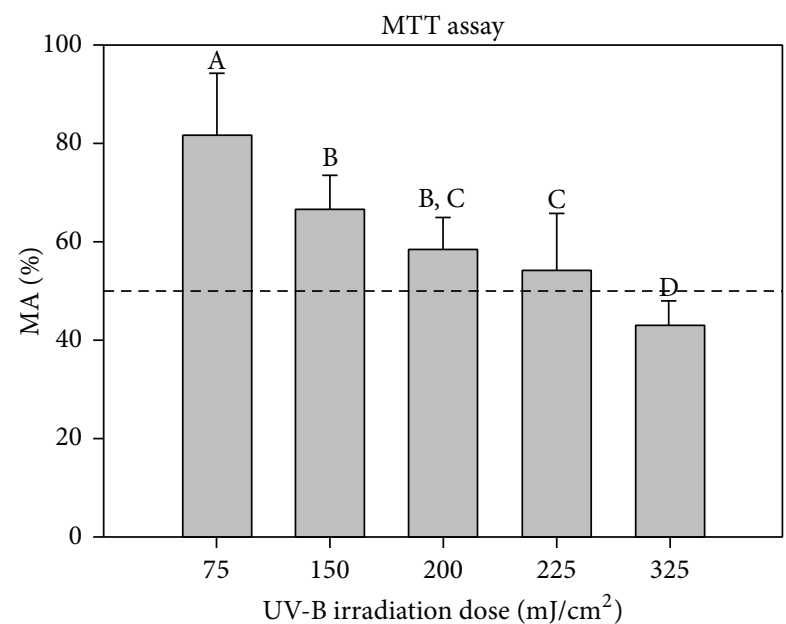

FIGURE 3: Effect of different UV-B doses on cell metabolic activity (MA) determined by MTT assay. Results are expressed as percentage (mean \pm SD) of cell MA compared to nonirradiated cells. Statistical analysis: One-Way ANOVA with All Pairwise Multiple Comparisons by Holm-Sidak method: statistical differences between the samples are represented by different letters when $P<0.05$.

the nonexposed cells. Higher lycopene concentrations could decrease the cell viability, for example, due to a prooxidant effect, as suggested by a decrease in viability compared to nonexposed, nonirradiated cells.

3.3. Cell Cycle Analysis. Figure 5 shows representative histograms of cell cycle of $\mathrm{HaCaT}$ cells after $10 \mu \mathrm{M}$ complexed lycopene exposure and UV-B irradiation $\left(225 \mathrm{~mJ} / \mathrm{cm}^{2}\right)$. Cell cycle analysis shows that complexed lycopene exposure alone did not significantly $(P>0.05)$ affect the dynamic of cell cycle in comparison to control cells. Compared to nonirradiated and nonexposed cells, irradiation induced a decrease in the percentage of cells in the G0/G1 phase of cell cycle especially in complexed lycopene and $\mathrm{CD}$ exposed cells $(P=0.011$ and

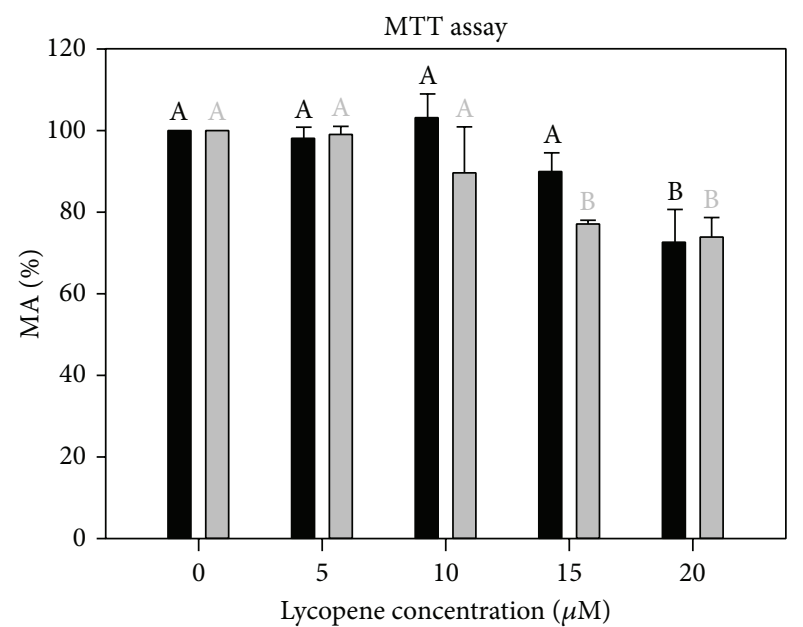

$$
\begin{aligned}
& \text { NI } \\
& \text { IR }
\end{aligned}
$$

FIGURE 4: Effect of complexed lycopene preexposure on UV-Birradiated (IR, $225 \mathrm{~mJ} / \mathrm{cm}^{2}$ ) and nonirradiated (NI) HaCaT cells on cell MA measured by MTT assay. Results are expressed as percentage (mean \pm SD of 3 independent experiments with 6 replicates each one). Statistical analysis: One-Way ANOVA with Multiple Comparisons versus Control Group (Holm-Sidak method): statistical differences between the samples within nonirradiated and irradiated groups (in respect to cells not exposed to lycopene) are represented by different letters when $P<0.05$.

0.008, resp.) (Figure 5). Although the S and G2 phases were not significantly affected by any of the treatments, an increase in S-phase frequency can be observed.

As previously observed in Figure 5, the analysis of PIstained nuclei by FCM cell cycle analysis showed an increase in sub-G1 subpopulations upon UVB irradiation. Exposure to $\mathrm{CD}$ vehicle induced a small decrease in \% sub-G1 irradiated cells, compared to nonexposed, irradiated cells. Contrarily to cells exposed to CD, cell exposed to Lyc-CD did not present 

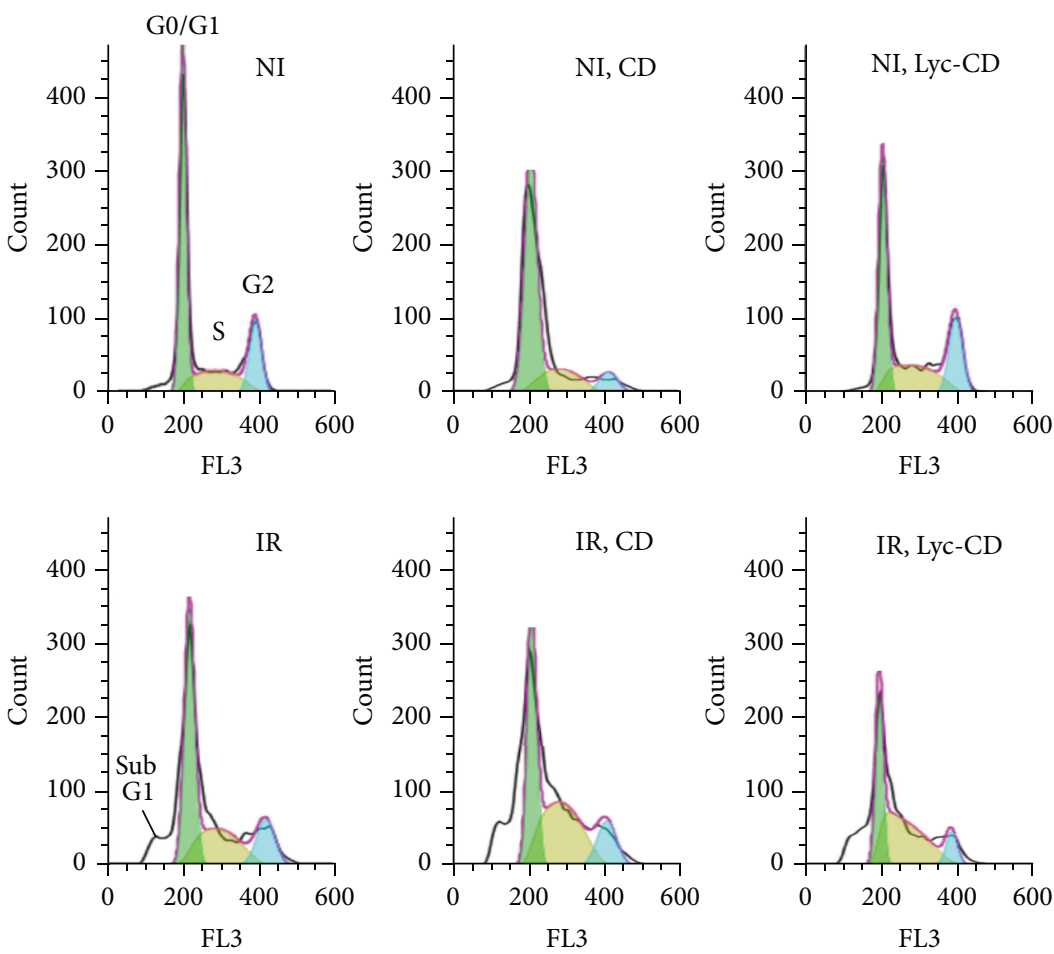

(a)

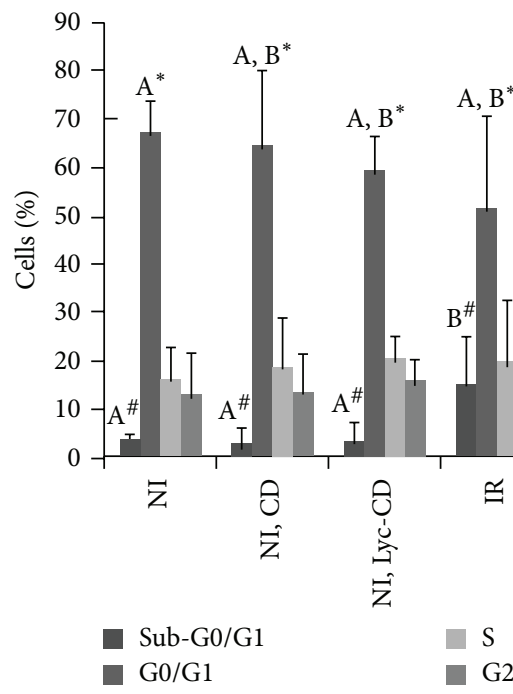

(b)

FIGURE 5: Effect of lycopene and UV-B on the cell cycle: (a) cell cycle histograms of UV-B $\left(225 \mathrm{~mJ} / \mathrm{cm}^{2}\right)$ irradiated (IR) and nonirradiated (NI) $\mathrm{HaCaT}$ cells exposed to $10 \mu \mathrm{M}$ complexed lycopene (Lyc-CD) and to the respective controls; (b) cell cycle phase distribution of UV-B $\left(225 \mathrm{~mJ} / \mathrm{cm}^{2}\right)$ irradiated (IR) and nonirradiated (NI) HaCaT cells exposed to $10 \mu \mathrm{M}$ complexed lycopene (Lyc-CD) and the respective controls, including cyclodextrin vehicle (NI, CD and IR, CD). Results are expressed as percentage (mean \pm SD). Statistical analysis: One-Way ANOVA with All Pairwise Multiple Comparison Procedures: means with different letters (A, B, and C) are significantly different $(P<0.05)$. In this case, only the statistical differences between groups presenting differences (G0/G1 and sub-G1) were marked for simplification purposes. Comparison between \% cells with sub-G1 amount of DNA (\#) and \% cells in G0/G1 phase $(*)$ is presented. 
small decrease in \% sub-G1, compared to nonexposed, irradiated cells.

3.4. Apoptotic Markers. Annexin V assay differentiates subpopulations that are necrotic, apoptotic, or viable. Comparative analysis of these subpopulations in irradiated $\left(225 \mathrm{~mJ} / \mathrm{cm}^{2}\right)$ and nonirradiated HaCaT cells, treated with $10 \mu \mathrm{M}$ complexed lycopene, was performed using the Annexin V assay (Figure 6).

Within this study, a high UVB dose was used to induce cell alterations and apoptosis, but not excessive necrosis. For this study only the adherent cells were analyzed, which means that the necrotic cells in suspension were not considered in the assay results. Nevertheless, as shown in Figure 6, the main shift upon UVB irradiation was from viable to apoptotic cells, confirming that the high UVB dose used was not excessively detrimental for the $\mathrm{HaCaT}$ cells attached to plate and used in all the assays described here. In nonirradiated cells, complexed lycopene did not affect $(P>0.05)$ the percentage of necrotic, apoptotic, and viable cells compared to the control (nonexposed cells). Contrarily, UV-B irradiation alone increased the percentage of both early and late apoptotic cells $(P<0.05)$ and decreased the percentage of viable cells compared to the control. Contrarily to what was observed for nonirradiated cells, the Annexin V assay showed a decrease in the \% cells with Annexin V positive staining (early and late apoptosis) preexposed to complexed lycopene in irradiated cells $(P<0.05)$, while the \% necrotic cells increased.

Also complementary data showed that irradiated cells previously exposed to the vehicle (CD) presented, once again, results quite similar to those of nonirradiated cells (supplementary data).

3.5. Effect of Complexed Lycopene on the Expression of Antiand Proapoptotic Genes. Under UVB irradiation, lycopene complex exerted proapoptotic effects compared to irradiated but not exposed cells (Figure 7). Compared to irradiated and nonexposed cells, in irradiated cells the exposure to vehicle $C D$ inhibited antiapoptotic BCL2 expression but did not increase proapoptotic $B A X$ expression. Contrarily to this, in irradiated cells Lyc-CD increased proapoptotic $B A X$ expression but did not inhibit antiapoptotic BCL2 expression. This observation points to a proapoptotic effect of Lyc-CD mediated by $B A X$ upregulation. Moreover, in irradiated cells Lyc-CD showed lower caspase 3 gene (CASP3) gene expression compared to nonexposed, irradiated cells; however, it increased CASP3 gene expression comparatively to $C D$ vehicle. TRAIL is a proapoptotic cytokine secreted by many cell types; however, in this study, UVB light was found to decrease TRAIL expression.

3.6. Reactive Oxygen Species (ROS) Analysis. Analysis of oxidative stress induction in HaCaT cells after $10 \mu \mathrm{M}$ complexed lycopene exposure and UV-B irradiation $(225 \mathrm{~mJ} /$ $\mathrm{cm}^{2}$ ) was performed by determining reactive oxygen species (ROS) formation by FCM.

The results of irradiated and nonirradiated cells are represented in Figure 8. UVB irradiation induced an increase in ROS intracellular production. In fact, regarding ROS production, two cell populations were observed in irradiated cells against one in nonirradiated cells. The Median Fluorescence Intensity (MFI) from irradiated samples was statistically higher than MFI from correspondent nonirradiated cells, as theoretically expected. Complexed lycopene did not increase ROS production in nonirradiated cells. However, in irradiated cells Lyc-CD induced a significant ROS increase compared to irradiated nonexposed cells.

\section{Discussion}

In this work, we used $\mathrm{HaCaT}$ cells, a "spontaneously transformed human epithelial cell line from adult skin" which maintains full epidermal differentiation capacity. This cell line is immortal (>140 passages) but remains nontumorigenic, and it is aneuploid (hypotetraploid) with unique stable marker chromosomes indicating monoclonal origin [40]. As performed in this experimental work, further investigation needs to include studies dealing with normal cells, their transformation into malignant cells, and the association between malignant cells and the surrounding normal cells in order to determine the cytotoxicity in both cell populations.

It is noteworthy that cell culture studies are usually carried out under abnormal conditions known as "culture shock," where cells are exposed to high oxygen tension and to free metal ions in the medium $[27,55]$. Thus, it must always be taken into account if the study compound reacts with the cell medium. Different half-life values of lycopene under standard cell culture are reported in the literature, for example, 12$20 \mathrm{~h}$ [37]. Experiments were conducted with exposure time of $24 \mathrm{~h}$ which was sufficient to reveal the cellular effects of Lyc-CD. Lycopene chemical stability was conferred by CD complexation.

The antioxidant action of carotenoids is related to their ability to trap free radicals and quench singlet oxygen. However, depending on the redox potential of lycopene and the surrounding environment, its antioxidant activity may shift to prooxidant activity $[56,57]$. In fact, the HaCaT cells medium (DMEM) contains ferric nitrate $\left(\mathrm{Fe}\left(\mathrm{NO}_{3}\right)_{3} \cdot 9 \mathrm{H}_{2} \mathrm{O}\right)$ and $\mathrm{Fe}$ (III) can react with excess neutral carotenoids, such as lycopene. Ferric ions have been proposed to degrade carotenoids by the following mechanism $[58,59]: \mathrm{Fe}^{3+}+$ carotenoid $\Rightarrow \mathrm{Fe}^{2+}+$ carotenoid $^{\bullet+}$. Although there are many Fe chelators that inhibit the reactions of Fe, oxygen, and their metabolites [60], these chelating agents may also mediate toxicity by stimulating Fe-mediated oxygen radical generation [61]. The chelating agent used for HaCaT trypsinization was ethylenediaminetetraacetic acid (EDTA) which can induce Fenton-chemistry mediated radical damage. In fact, the autoxidation of Fe(II) enhanced by EDTA was observed by others $[57,58]$. Therefore, in order to prevent lycopene oxidation by Fe (III), another cell culture medium ( $\alpha$-MEM) was used without this element during cells exposure to lycopene. A normal cellular growth was observed. Furthermore, it should be also noted that the solution with the highest lycopene dose had a suitable osmolarity lower than $320 \mathrm{mOsm} / \mathrm{kg}$ ( 268 mOsm/kg).

During storage, special precautions were taken such as the protection of lycopene from temperature, light, and 

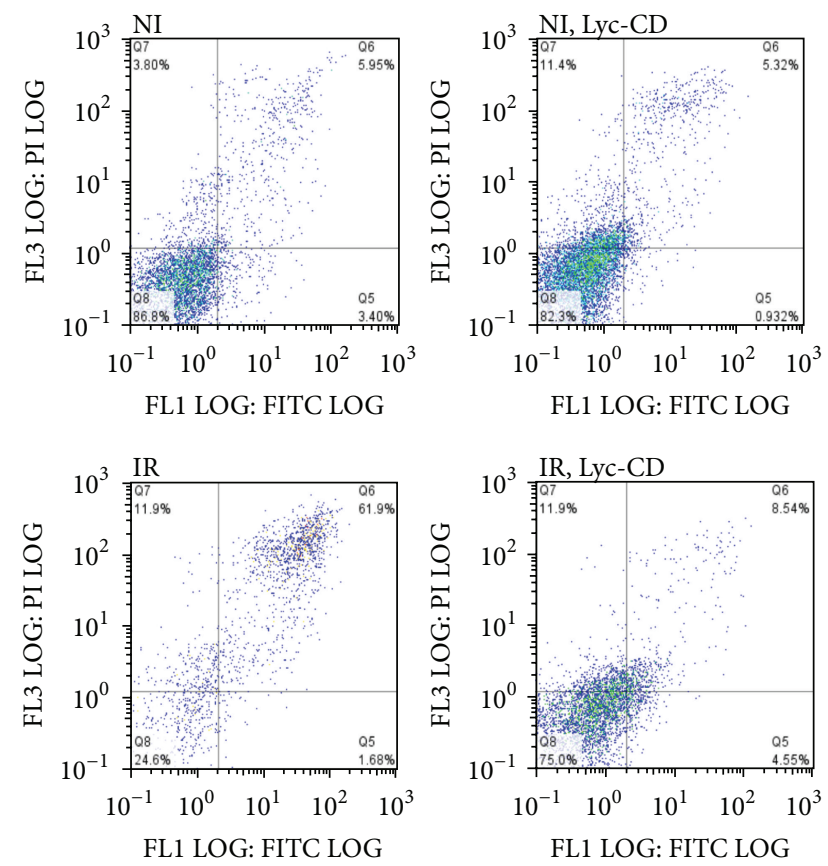

(a)

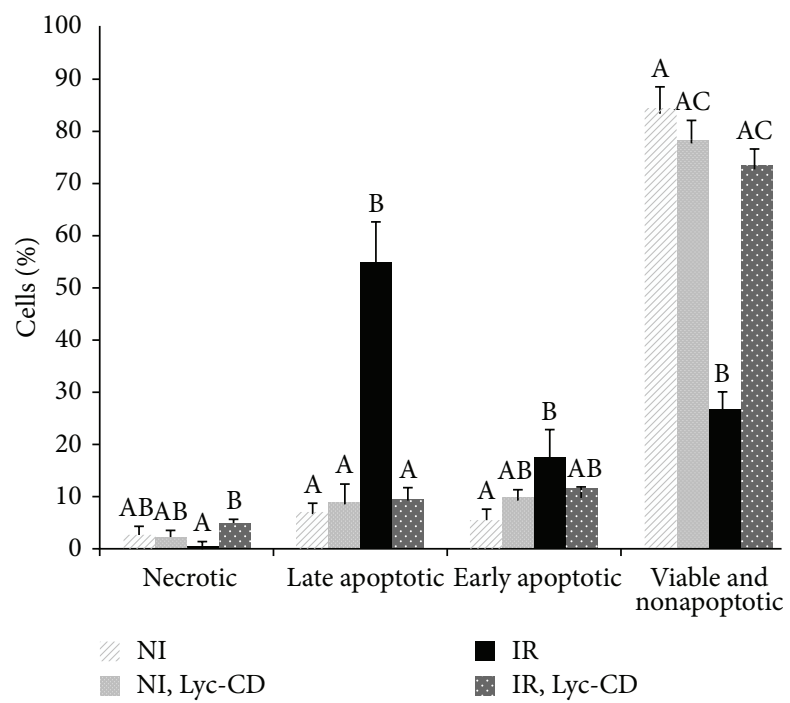

(b)

FIgURE 6: (a) Representative examples of Annexin V-FITC Dot-Plots Gating (FL1 LOG versus FITC LOG) of nonirradiated (NI) and UV-B $\left(225 \mathrm{~mJ} / \mathrm{cm}^{2}\right)$ irradiated (IR) HaCaT cells not previously exposed or exposed to $10 \mu \mathrm{M}$ complexed lycopene (Lyc-CD); (b) results are expressed as percentage (mean $\pm \mathrm{SD}, n=3$ ) of nonapoptotic and viable cells, Q8: Annexin-FTIC (-) and PI (-); early apoptotic cells, Q5: Annexin-FTIC $(+)$ and PI (-); predominantly late apoptotic or dead cells, Q6: Annexin- FTIC (+) and PI (+); and predominantly necrotic and dead cells, Q7: Annexin-FTIC (-) and PI (+). Statistical analysis: One-Way ANOVA with All Pairwise Multiple Comparison Procedures (Holm-Sidak method): means with different letters are significantly different $(P<0.05)$.

air. However, during lycopene exposure, cell culture was maintained at $37^{\circ} \mathrm{C}$ in a humidified incubator with $5 \% \mathrm{CO}_{2}$ atmosphere. Even considering other experimental conditions reported in the literature [62] that comprise the addition of lycopene solutions to the cell culture medium under $\mathrm{N}_{2}$ environment, we preferred to maintain our protocol to avoid perturbing the cell culture with other variables.

The level of lycopene normally observed in human plasma is on the order of $0.5 \mu \mathrm{M}$ even with dietary supplementation $[20,52,53]$. Therefore, for therapeutic purposes (assuming topical application) we used a range above these normal plasma levels (5 up to $20 \mu \mathrm{M}$ ). According to MTT results, $20 \mu \mathrm{M}$ is revealed to be toxic in in vitro studies (Figure 4). Thus, $10 \mu \mathrm{M}$ lycopene nominal concentration was selected for further studies, supporting the selected dose used in other in vitro studies [52-54].

The option to use cyclodextrins for lycopene solubilization and photoprotection was based on data resulting from previous studies (Table 1) on parameters/conditions affecting the delivery of lycopene to cells, including the solubilization, stabilization, and cellular uptake by using other vehicles. In addition, similar MTT results were obtained with another vehicle (supplementary data).

$\mathrm{HaCaT}$ keratinocytes have a mean intermitotic time of $22-24 \mathrm{~h}$ in vitro [13] and their cell cycle is subjected to regulation by cyclins, cyclin-dependent kinases (CDKs), and CDK inhibitors.
UV-B irradiation activates diverse cellular responses in human cells, such as cell cycle arrest, DNA repair, and apoptosis through signal transduction pathways [15]. Previous studies have shown that UVR can cause cell cycle arrest both at G1 [63] and G2 phases [64] of cell cycle. However, in our study, irradiation did not affect significantly the percentage of cells on S and G2 phases (Figure 5). On the contrary, the percentage of cells in G1 phase decreased in irradiated cells, especially those previously exposed to complexed lycopene or the respective vehicle alone (cyclodextrins). Cyclin D regulates the transition from G0 to early G1 phase, while cyclin $\mathrm{E}$ regulates the transition of the cell from late Gl phase to $S$ phase; p21 and p27 CDK inhibitors bind and inhibit the activity of cyclin E/CDK2 complex, blocking cell cycle progression in G1 phase. In fact, after UV irradiation, the half-life of the tumor suppressor (p53) appears to be extended which will induce the p21 CDK inhibitor leading to G1 phase arrest or cell death by apoptosis. G2-phase checkpoint control does not appear to be affected [65]. It has been reported that the growth inhibition of lycopene on MCF-7 breast cancer cells was also associated with decreased G1-S cell cycle progression, decreased cyclin D1 expression, and stabilization of p27 in the cyclin E-CDK complex [7, 66]. Cell cycle arrest increases the time available for DNA repair before its replication and mutation fixation processes [5]. Regarding the cell cycle results obtained with $\mathrm{CD}$, it has been reported that methyl $\beta$-CD inhibits cell growth and induces cell cycle arrest 

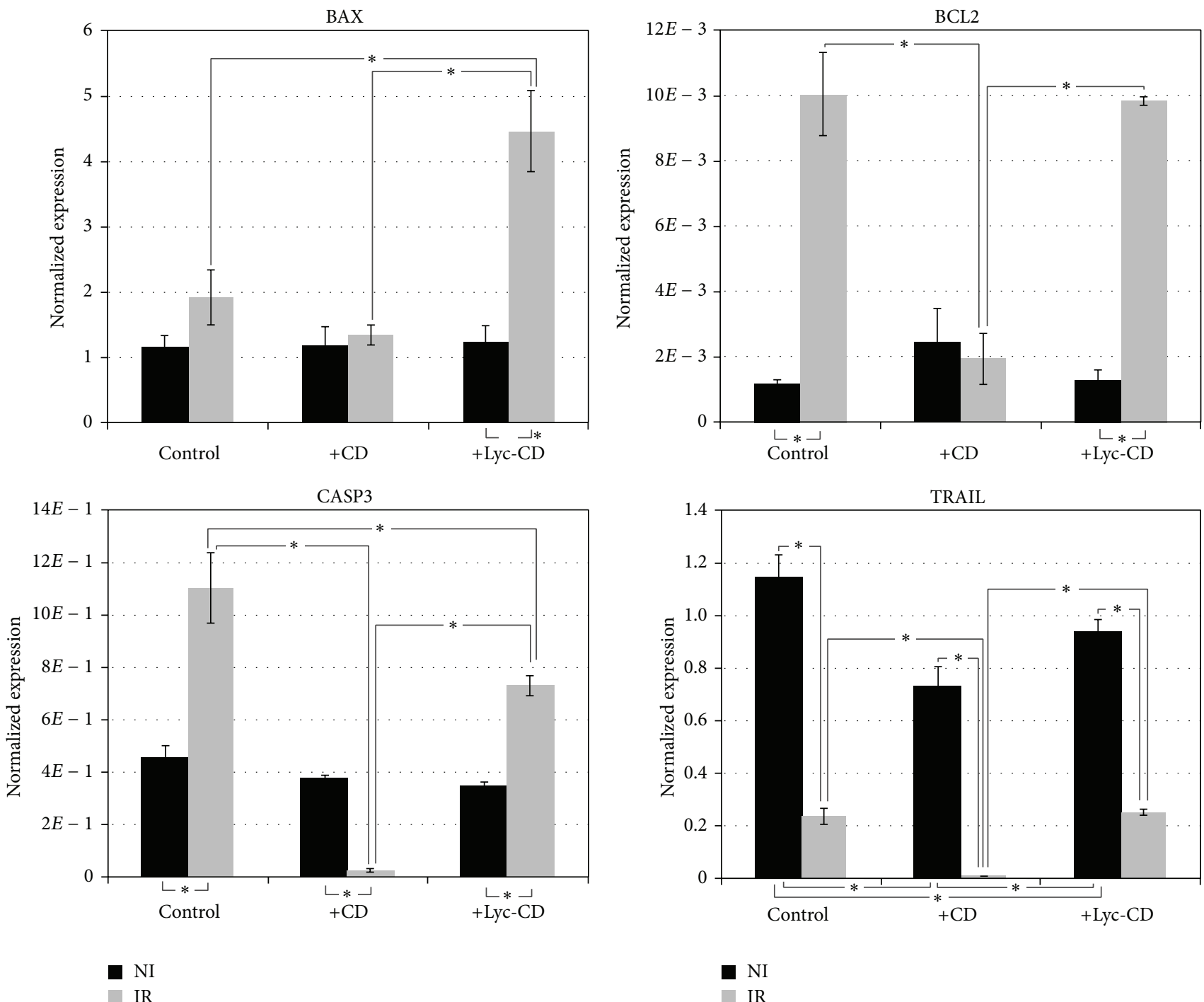

FIGURE 7: Representation of Bax, Bcl-2, caspase 3, and TRAIL gene expression values in HaCaT cells exposed to $10 \mu \mathrm{M}$ complexed lycopene (Lyc-CD) normalized to the SDHA reference gene. Cells were irradiated with $225 \mathrm{~mJ} / \mathrm{cm}^{2} \mathrm{UV}$-B (IR) and nonirradiated (NI). Results are expressed as mean \pm SEM of three technical replicates from two independent assays.

via a prostaglandin E2 independent pathway in Raw264.7 macrophage cells [67]. Thus, a control assay with CD alone is mandatory in these studies.

Apoptosis is the best-characterized type of programmed cell death because of its importance in development, homeostasis, and pathogenesis of different diseases, such as cancer. Cells respond to specific apoptotic signals by initiating intracellular processes that result in typical physiological changes. Among these changes are externalization of phosphatidylserine to the cell surface, depolarization of mitochondrial membranes, cleavage and degradation of specific cellular proteins, compaction and fragmentation of nuclear chromatin, loss of cell membrane integrity, and cellular shrinkage. We studied one of the earliest apoptotic events, that is, the translocation of phosphatidylserine (PS) from the inner to the outer leaflet of the plasma membrane. Moreover, Bowen et al. [68] have found that $\mathrm{HaCaT}$ cell line (which harbors two mutant p53 alleles) are more susceptible to apoptosis than normal keratinocytes in vitro, possibly because of aberrant signaling pathways resulting from long-term culture $[69,70]$.

In this work, a decrease in \% apoptotic cells was observed in irradiated cells preexposed to Lyc-CD (Figure 6). However, this result must be interpreted cautiously, as CD has been previously reported to deplete cholesterol from cell membranes [71, 72]. Cholesterol presence is essential for lipid raft formation and Fas-receptor activation, and this could inhibit UV-B induced apoptosis, as demonstrated by George et al. [73]. Depletion of cholesterol by methyl- $\beta$-cyclodextrin reduced Fas aggregation which was accompanied with a reduced apoptotic but increased nonapoptotic death of UV$\mathrm{B}$-irradiated $\mathrm{HaCaT}$ cells [73]. In preliminary experiments, we in fact observed that $\mathrm{CD}$ alone can decrease the \% apoptotic cells (supplementary data). Moreover, since CD can form complexes with lipids from the plasma membrane, it 


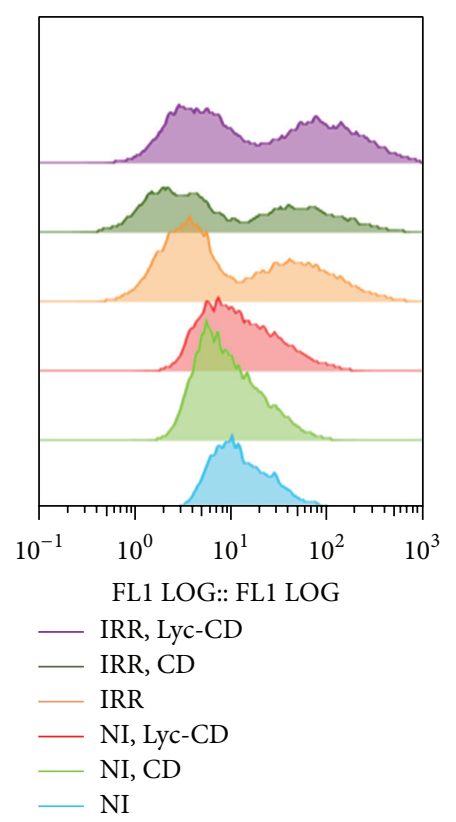

(a)

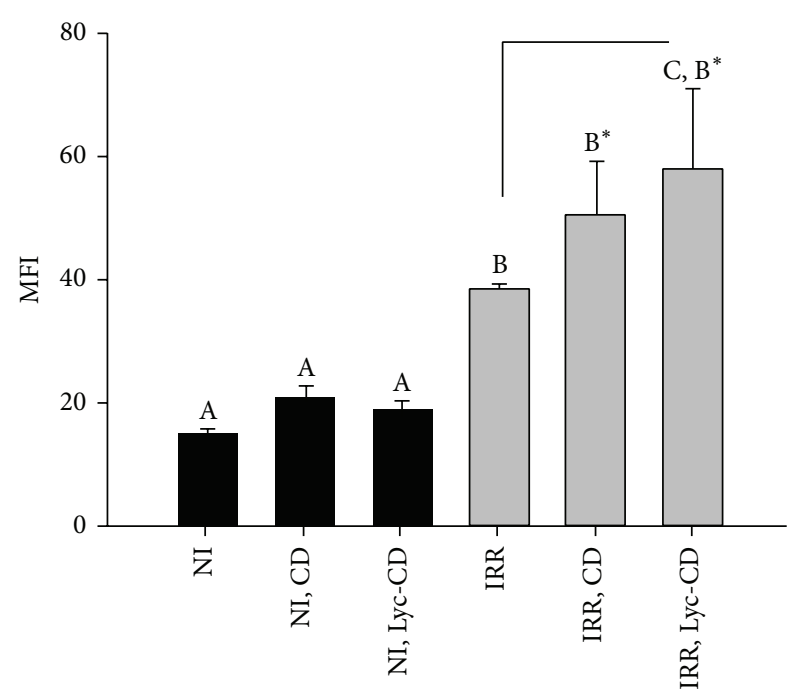

(b)

FIGURE 8: Intracellular ROS quantification: (a) FL1 histogram plots, showing the distribution of cell count versus DCF fluorescence, and (b) Mean Fluorescence Intensity (MFI) histograms results of HaCaT UV-B irradiated cells, IR $\left(225 \mathrm{~mJ} / \mathrm{cm}^{2}\right)$, and nonirradiated cells (NI) exposed to $10 \mu \mathrm{M}$ complexed lycopene (Lyc-CD) and to the respective controls labelled with DCF-DA. Statistical analysis: One-Way ANOVA with Multiple Pairwise Comparisons: medians with different letters are significantly different $(P<0.05)$.

might be possible that PS was shielded by $\mathrm{CD}$ against binding to Annexin V, a requirement for the validity of Annexin $\mathrm{V}$ assay. Nevertheless, cells exposed to Lyc-CD showed an increase in the $\mathrm{Bax} / \mathrm{Bcl} 2$ gene expression ratio. Moreover, Lyc-CD completely reverted the inhibitory effect of CD in TRAIL expression. These results suggest a proapoptotic effect of lycopene which is not found in CD. UV-B irradiation has been shown to increase levels of apoptosis biomarkers, especially the proapoptotic protein Bax, thereby inducing apoptosis in skin cells. Regarding the apoptosis biomarkers, $\mathrm{Bcl}-2$ family proteins can modulate mitochondrial permeability through oxidative phosphorylation during apoptosis. Changes in the $\mathrm{Bax} / \mathrm{Bcl}-2$ ratio suggest a corresponding change in mitochondrial permeability to release apoptogenic molecules from the mitochondria to the cytosol [5]. In this work, irradiated cells showed significantly higher levels of apoptosis, confirmed by independent parameters (namely, increased sub-G1 population indicative of DNA fragmentation) and binding to Annexin V, indicative of increased phosphatidylserine present in the outer leaflet of the cell membrane. From the gene expression data obtained, this means that the most relevant parameters to take into account for UVB-induced apoptosis are BAX and CASP3 expression. $B C L 2$, a known antiapoptotic effector was found upregulated in this study, and TRAIL, a proapoptotic cytokine, was found downregulated under UVB irradiation. This suggests that under the experimental conditions used, these genes have a comparatively lower predictive value for apoptosis induction by UVB. It might be a response at transcription level which does not reflect the physiological level of the irradiated cells.
A more close focus on $B A X$ and CASP3 expression reveals that lycopene induced increased $B A X$ expression in cells treated with the high UVB dose used in this study and this might represent an important mechanism for its therapeutic action.

Besides apoptosis, necroptosis, and necrosis or senescence, damaged keratinocytes can also be physiologically eliminated by induction of terminal differentiation. This may be readily monitored by detection of, for example, "suprabasal" keratins or cytoplasmic involucrin for late steps in epidermal differentiation; however, this type of analysis would probably be most useful for very late time points. It should be noted that more biomarkers could be also analyzed considering the huge cascade events triggered by UVR, for example, protein kinase $\mathrm{C}$ family which sensitizes skin to UVR [74] and others regarding the influence on intracellular calcium levels or retinol signaling which are profoundly altered upon differentiation of keratinocytes [75].

UVR results in an increased generation of ROS that interacts with proteins, lipids, and DNA, overwhelming the antioxidant defense mechanisms of the cells.

The epidermis is composed mainly of keratinocytes, which are rich in ROS detoxifying enzymes such as superoxide dismutase, catalase, and glutathione peroxidase and in low-molecular-mass antioxidant molecules [76]. Although skin spontaneously responds to increased ROS levels, this response may not be sufficient to prevent the progression of skin cancer [4]. Despite the extensive evidence implicating ROS in oxidative DNA damage, little is known about its involvement in DNA damage of keratinocytes, which are the 
most relevant cell type in nonmelanoma skin cancer. The singlet oxygen and hydroxyl radicals are the major damaging oxidative species which can be formed under normal aerobic metabolism and by certain processes including photosensitization [77]. The major DNA oxidation products include 8oxo-7-hydro-deoxy-guanosine (8-oxodG) and 2,6-diamino4-hydroxy-5-formamidopyrimidine [78].

Comparatively to nonirradiation, UV-B irradiation significantly altered the distribution of cells in terms of fluorescence (Figure 8). In irradiated cells two populations can be distinguished. The first peak might correspond to dead cells, which had a very weak signal of DCF (compatible with autofluorescence). In this case, the DCF might not be activated and metabolized within the cell (no fluorescence), and/or the cells might not retain the DCF because of the loss of membrane integrity. Complexed lycopene increased the ROS levels in irradiated cells. Reagan-Shaw et al. [5] have also obtained a significant decrease of SOD activity (MnSOD) after treatment with sanguinarine, enhancing UV-B-mediated oxidative stress in HaCaT cells. However, according to Onoue et al. [79], ROS data might not always provide a reliable indication for the capacity of a chemical to participant in a photogenotoxic cascade. This fact could be more realistic when irradiation is used in experiments. In fact, the photodegradation of lycopene may contribute to cytotoxicity, including oxidative damage. For example, apo-6 ${ }^{\prime}$-lycopene and 2-methyl-hepte-6-one as well as further reaction products are formed during irradiation of lycopene $[28,80]$. Nagao [81] found that oxidized metabolites of lycopene but not lycopene itself can inhibit cell growth and stimulate apoptosis in a different cell line (HL-60). In another study, lycopene in human prostate cancer cells inhibited cell growth, but the oxidized mixtures displayed markedly more potent growth inhibition [81, 82]. On the contrary, some recent studies suggested that lycopene or lycopene metabolites may, as $\beta$-carotene and its metabolites do, enhance carcinogenesis.

In general, similar results were obtained by Reagan-Shaw et al. [5] who suggested that sanguinarine (also a botanical antioxidant) may protect skin cells (also HaCaT cell line) from UVB-mediated damage via apoptotic elimination of damaged cells that escaped from the programmed cell death. These are clearly important observations since apoptosis is a mechanism of defense and acts by opposing the creation of damaged and preneoplastic cells and expansion to a clone. Once mutations arise, apoptosis also removes preneoplastic cells that are aberrantly proliferating due to genetic defects.

However, further investigation into the dose effect of lycopene and further understanding of the metabolism of apo-10'-lycopenoids on carcinogenesis are still needed [7]. On the other hand, studies on skin organotypic 3D-cocultures (long-lived 3D-cocultures, epiSC-markers, label-retaining cells, etc.) would be useful to have all picture considering the loss of complex interactions between the epithelium and stroma in 2D cell cultures [83]. An UV-irradiation protocol for a normal skin model or even the malignant model for both prevention and treatment approaches of skin cancer could be used $[84,85]$.

\section{Conclusions}

According to data obtained from all experimental assays, we demonstrate here that complexed lycopene up to $10 \mu \mathrm{M}$ does not show metabolic toxicity (MTT assay) under standard cell culture conditions. On one hand, at nontoxic dose $(10 \mu \mathrm{M})$ complexed lycopene does not affect the profile of apoptotic, necrotic, and viable cells or show cytostatic effects despite slightly increasing the ROS content. However, cells previously exposed to complexed lycopene when irradiated with metabolically damaging UV-B dose show a distinguishing switch in the dead:apoptotic: viable subpopulations compared to nonexposed irradiated cells. On the other hand, exposed irradiated cells showed a decrease in G0/G1 phase. In fact, the increased sub-G0/G1 phase and a trend for Sphase delay (even not statistically different) could contribute to this cell cycle change. In addition, an increased expression of different apoptosis biomarkers ( $B A X$ and caspase 3 ) was observed in exposed irradiated cells when compared to the respective controls. These two biomarkers were the most useful probably because those genes might be more involved in this process.

Therefore, complexed lycopene might play a corrective role or cytotoxic effect in photodamaged and preneoplastic keratinocytes, while allowing other keratinocytes to accelerate repairing mechanisms becoming viable. However, some results could be altered by the $\mathrm{CD}$ interference with some in vitro assays and also with the cells particularly after a high damage effect. Although CDs seemed to be a good candidate to vehicle lycopene in order to counterbalance the disadvantages of most solvents usually used, here we found that it was not suitable under this protocol conditions, especially UV irradiation. Nevertheless, these are interesting data regarding the $\mathrm{CD}$ effect on cell cultures and reveal the importance of the analysis of this control compared to cells exposed to active molecules, as it was here performed.

Future studies will continue with other exposure conditions, that is, another lycopene vehicle and a lower UV-B dose which could be set by other assays, such as TUNEL and/or detection of chromosomal breakage by Cytokinesis-Blocked Micronucleus Cytome Assay (CBMN) (besides MTT). Moreover, detection of $\mathrm{Ki} 67$ protein, a marker of proliferation, could be attempted. The analysis of other biomarkers and final studies using 3D skin models as previously suggested would resemble more closely the situation in vivo, which may give definite and clear answers.

\section{Conflict of Interests}

All authors have no conflict of interests to declare.

\section{Acknowledgments}

This work has been funded by the European Regional Development Fund (FEDER) through the Competitive Factors Thematic Operational Programme (COMPETE) and by National Funds through the Foundation for Science and Technology (FCT), under the projects PEst-OE/SAU/ UI4013/2011 and UID/AMB/50017/2013. The grants awarded 
by FCT to Helena Oliveira (SFRH/BPD/48853/2008) and José Miguel P. Ferreira de Oliveira (SFRH/BPD/74868/2010) are also acknowledged. The authors acknowledge Dr. Armando Costa for technical support.

\section{References}

[1] A. Svobodová, J. Psotová, and D. Walterová, "Natural phenolics in the prevention of UV-induced skin damage. A review," Biomedical Papers, vol. 147, no. 2, pp. 137-145, 2003.

[2] W. Stahl, U. Heinrich, O. Aust, H. Tronnier, and H. Sies, "Lycopene-rich products and dietary photoprotection," Photochemical \& Photobiological Sciences, vol. 5, no. 2, pp. 238-242, 2006.

[3] F. Afaq and H. Mukhtar, "Botanical antioxidants in the prevention of photocarcinogenesis and photoaging," Experimental Dermatology, vol. 15, no. 9, pp. 678-684, 2006.

[4] F. Afaq, D. N. Syed, A. Malik et al., "Delphinidin, an anthocyanidin in pigmented fruits and vegetables, protects human $\mathrm{HaCaT}$ keratinocytes and mouse skin against UVB-mediated oxidative stress and apoptosis," Journal of Investigative Dermatology, vol. 127, no. 1, pp. 222-232, 2007.

[5] S. Reagan-Shaw, J. Breur, and N. Ahmad, "Enhancement of UVB radiation-mediated apoptosis by sanguinarine in $\mathrm{HaCaT}$ human immortalized keratinocytes," Molecular Cancer Therapeutics, vol. 5, no. 2, pp. 418-429, 2006.

[6] A. T. Dinkova-Kostova, "Phytochemicals as protectors against ultraviolet radiation: versatility of effects and mechanisms," Planta Medica, vol. 74, no. 13, pp. 1548-1559, 2008.

[7] J. R. Mein, F. Lian, and X.-D. Wang, "Biological activity of lycopene metabolites: implications for cancer prevention," Nutrition Reviews, vol. 66, no. 12, pp. 667-683, 2008.

[8] W. Stahl and H. Sies, "Carotenoids and flavonoids contribute to nutritional protection against skin damage from sunlight," Molecular Biotechnology, vol. 37, no. 1, pp. 26-30, 2007.

[9] J. D. Ribaya-Mercado, M. Garmyn, B. A. Gilchrest, and R. M. Russell, "Skin lycopene is destroyed preferentially over $\beta$ carotene during ultraviolet irradiation in humans," The Journal of Nutrition, vol. 125, no. 7, pp. 1854-1859, 1995.

[10] H. Salman, M. Bergman, M. Djaldetti, and H. Bessler, "Lycopene affects proliferation and apoptosis of four malignant cell lines," Biomedicine \& Pharmacotherapy, vol. 61, no. 6, pp. 366-369, 2007.

[11] R. Zefferino, A. Leone, S. Piccaluga, R. Cincione, and L. Ambrosi, "Mercury modulates interplay between IL-1 $\beta$, TNF$\alpha$, and gap junctional intercellular communication in keratinocytes: mitigation by lycopene," Journal of Immunotoxicology, vol. 5, no. 4, pp. 353-360, 2008.

[12] D. E. Brash and P. A. Havre, "New careers for antioxidants," Proceedings of the National Academy of Sciences of the United States of America, vol. 99, no. 22, pp. 13969-13971, 2002.

[13] J. A. McGrath and J. Uitto, "Anatomy and organization of human skin," in Rook's Textbook of Dermatology, pp. 1-53, WileyBlackwell, 2010.

[14] M. Andreassi and L. Andreassi, "Antioxidants in dermocosmetology: from the laboratory to clinical application," Journal of Cosmetic Dermatology, vol. 2, no. 3-4, pp. 153-160, 2003.

[15] T. P. Heffernan, M. Kawasumi, A. Blasina, K. Anderes, A. H. Conney, and P. Nghiem, "ATR-Chk1 pathway inhibition promotes apoptosis after UV treatment in primary human keratinocytes: potential basis for the UV protective effects of caffeine," Journal of Investigative Dermatology, vol. 129, no. 7, pp. 1805-1815, 2009.

[16] Z. Fazekas, D. Gao, R. N. Saladi, Y. Lu, M. Lebwohl, and H. Wei, "Protective effects of lycopene against ultraviolet B-induced photodamage," Nutrition and Cancer, vol. 47, no. 2, pp. 181-187, 2003.

[17] L. Tang, T. Jin, X. Zeng, and J.-S. Wang, "Lycopene inhibits the growth of human androgen-independent prostate cancer cells in vitro and in BALB/c nude mice," The Journal of Nutrition, vol. 135, no. 2, pp. 287-290, 2005.

[18] I. Pfitzner, P. I. Francz, and H. K. Biesalski, "Carotenoid:methyl$\beta$-cyclodextrin formulations: an improved method for supplementation of cultured cells," Biochimica et Biophysica ActaGeneral Subjects, vol. 1474, no. 2, pp. 163-168, 2000.

[19] E. A. Offord, J.-C. Gautier, O. Avanti et al., "Photoprotective potential of lycopene, $\beta$-carotene, vitamin $\mathrm{E}$, vitamin $\mathrm{C}$ and carnosic acid in UVA-irradiated human skin fibroblasts," Free Radical Biology and Medicine, vol. 32, no. 12, pp. 1293-1303, 2002.

[20] X. Xu, Y. Wang, A. I. Constantinou, M. Stacewicz-Sapuntzakis, P. E. Bowen, and R. B. Van Breemen, "Solubilization and stabilization of carotenoids using micelles: delivery of lycopene to cells in culture," Lipids, vol. 34, no. 10, pp. 1031-1036, 1999.

[21] N. Augé, N. Santanam, and S. Parthasarathy, "An efficient method for solubilizing $\beta$-carotene in aqueous solutions," Journal of Medicinal Food, vol. 1, no. 1, pp. 39-43, 1998.

[22] A. W. Williams, T. W.-M. Boileau, S. K. Clinton, and J. W. Erdman Jr., " $\beta$-carotene stability and uptake by prostate cancer cells are dependent on delivery vehicle," Nutrition and Cancer, vol. 36, no. 2, pp. 185-190, 2000.

[23] A. Junghans, H. Sies, and W. Stahl, "Carotenoid-containing unilamellar liposomes loaded with glutathione: a model to study hydrophobic-hydrophilic antioxidant interaction," Free Radical Research, vol. 33, no. 6, pp. 801-808, 2000.

[24] P. Palozza, R. Muzzalupo, S. Trombino, A. Valdannini, and N. Picci, "Solubilization and stabilization of $\beta$-carotene in niosomes: delivery to cultured cells," Chemistry and Physics of Lipids, vol. 139, no. 1, pp. 32-42, 2006.

[25] Y. Rahimpour and H. Hamishehkar, "Liposomes in cosmeceutics," Expert Opinion on Drug Delivery, vol. 9, no. 4, pp. 443-455, 2012.

[26] E. B. Souto, R. H. Müller, and A. J. Almeida, "Topical delivery of oily actives using solid lipid particles," Pharmaceutical Technology Europe, vol. 19, no. 12, pp. 28-32, 2007.

[27] C.-Y. Lin, C.-S. Huang, and M.-L. Hu, "The use of fetal bovine serum as delivery vehicle to improve the uptake and stability of lycopene in cell culture studies," British Journal of Nutrition, vol. 98, no. 1, pp. 226-232, 2007.

[28] S.-L. Yeh, C.-S. Huang, and M.-L. Hu, "Lycopene enhances UVA-induced DNA damage and expression of heme oxygenase-1 in cultured mouse embryo fibroblasts," European Journal of Nutrition, vol. 44, no. 6, pp. 365-370, 2005.

[29] S. Shahrzad, E. Cadenas, A. Sevanian, and L. Packer, "Impact of water-dispersible beadlets as a vehicle for the delivery of carotenoids to cultured cells," BioFactors, vol. 16, no. 3-4, pp. 8391, 2002.

[30] J. S. Hurst, J. E. Centreras, W. G. Siems, and F. J. G. M. Van Kuijk, "Oxidation of carotenoids by heat and tobacco smoke," BioFactors, vol. 20, no. 1, pp. 23-35, 2004.

[31] S. M. O'Sullivan, J. A. Woods, and N. M. O'Brien, "Use of Tween 40 and Tween 80 to deliver a mixture of phytochemicals 
to human colonic adenocarcinoma cell (CaCo-2) monolayers," British Journal of Nutrition, vol. 91, no. 5, pp. 757-764, 2004.

[32] C.-S. Huang, M.-K. Shih, C.-H. Chuang, and M.-L. Hu, "Lycopene inhibits cell migration and invasion and upregulates Nm23-H1 in a highly invasive hepatocarcinoma, SK-Hep-1 cells," The Journal of Nutrition, vol. 135, no. 9, pp. 2119-2123, 2005.

[33] G. Da Violante, N. Zerrouk, I. Richard, G. Provot, J. C. Chaumeil, and P. Arnaud, "Evaluation of the cytotoxicity effect of dimethyl sulfoxide (DMSO) on Caco2/TC7 colon tumor cell cultures," Biological and Pharmaceutical Bulletin, vol. 25, no. 12, pp. 1600-1603, 2002.

[34] A. M. Rodríguez, S. Sastre, J. Ribot, and A. Palou, "Betacarotene uptake and metabolism in human lung bronchial epithelial cultured cells depending on delivery vehicle," Biochimica et Biophysica Acta-Molecular Basis of Disease, vol. 1740, no. 2, pp. 132-138, 2005.

[35] M. D. Gross, T. D. Bishop, J. D. Belcher, and D. R. Jacobs Jr., "Solubilization of $\beta$-carotene in culture media," Nutrition and Cancer, vol. 27, no. 2, pp. 174-176, 1997.

[36] K. R. Martin, G. Loo, and M. L. Failla, "Human lipoproteins as a vehicle for the delivery of $\beta$-carotene and $\alpha$-tocopherol to HepG2 cells," Proceedings of the Society for Experimental Biology and Medicine, vol. 214, no. 4, pp. 367-378, 1997.

[37] R. V. Cooney, T. J. Kappock, A. Pung, and J. S. Bertram, “[6] Solubilization, cellular uptake, and activity of $\beta$-carotene and other carotenoids as inhibitors of neoplastic transformation in cultured cells," in Methods in Enzymology, P. Lester, Ed., vol. 214, pp. 55-68, Academic Press, 1993.

[38] R. R. Wei, W. G. Wamer, L. A. Lambert, and A. Kernhauser, “ $\beta$ Carotene uptake and effects on intracellular levels of retinol in vitro," Nutrition and Cancer, vol. 30, no. 1, pp. 53-58, 1998.

[39] R. B. van Breemen and N. Pajkovic, "Multitargeted therapy of cancer by lycopene," Cancer Letters, vol. 269, no. 2, pp. 339-351, 2008.

[40] P. Boukamp, R. T. Petrussevska, D. Breitkreutz, J. Hornung, A. Markham, and N. E. Fusenig, "Normal keratinization in a spontaneously immortalized aneuploid human keratinocyte cell line," Journal of Cell Biology, vol. 106, no. 3, pp. 761-771, 1988.

[41] K. Park and J.-H. Lee, "Protective effects of resveratrol on UVB-irradiated $\mathrm{HaCaT}$ cells through attenuation of the caspase pathway," Oncology Reports, vol. 19, no. 2, pp. 413-417, 2008.

[42] L. Struijk, E. van der Meijden, S. Kazem et al., "Specific betapapillomaviruses associated with squamous cell carcinoma of the skin inhibit UVB-induced apoptosis of primary human keratinocytes," Journal of General Virology, vol. 89, no. 9, pp. 2303-2314, 2008.

[43] K. Park and J.-H. Lee, "Photosensitizer effect of curcumin on UVB-irradiated HaCaT cells through activation of caspase pathways," Oncology Reports, vol. 17, no. 3, pp. 537-540, 2007.

[44] E. M. Bruzell, E. Morisbak, and H. H. Tønnesen, "Studies on curcumin and curcuminoids. XXIX. Photoinduced cytotoxicity of curcumin in selected aqueous preparations," Photochemical \& Photobiological Sciences, vol. 4, no. 7, pp. 523-530, 2005.

[45] M. Athar, A. L. Kim, N. Ahmad, H. Mukhtar, J. Gautier, and D. R. Bickers, "Mechanism of ultraviolet B-induced cell cycle arrest in G2/M phase in immortalized skin keratinocytes with defective p53," Biochemical and Biophysical Research Communications, vol. 277, no. 1, pp. 107-111, 2000.

[46] J. M. P. F. de Oliveira, C. Remédios, H. Oliveira et al., "Sulforaphane induces DNA damage and mitotic abnormalities in human osteosarcoma MG-63 cells: correlation with cell cycle arrest and apoptosis," Nutrition and Cancer, vol. 66, no. 2, pp. 325-334, 2014.

[47] J. M. P. Ferreira de Oliveira, M. Costa, T. Pedrosa et al., "Sulforaphane induces oxidative stress and death by p53independent mechanism: Implication of impaired glutathione recycling," PLoS ONE, vol. 9, no. 3, Article ID e92980, 2014.

[48] S. Rozen and H. Skaletsky, "Primer3 on the WWW for general users and for biologist programmers," Methods in Molecular Biology, vol. 132, pp. 365-386, 2000.

[49] J. Kent, UCSC in Silico PCR, 2013, http://genome.ucsc.edu/ cgi-bin/hgPcr?command=start.

[50] S. Zhao and R. D. Fernald, "Comprehensive algorithm for quantitative real-time polymerase chain reaction," Journal of Computational Biology, vol. 12, no. 8, pp. 1047-1064, 2005.

[51] M. W. Pfaffl, "A new mathematical model for relative quantification in real-time RT-PCR," Nucleic Acids Research, vol. 29, no. 9, article e45, 2001.

[52] W. Stahl and H. Sies, "Lycopene: a biologically important carotenoid for humans?" Archives of Biochemistry and Biophysics, vol. 336, no. 1, pp. 1-9, 1996.

[53] W. H. F. Sutherland, R. J. Walker, S. A. De Jong, and J. E. Upritchard, "Supplementation with tomato juice increases plasma lycopene but does not alter susceptibility to oxidation of low-density lipoproteins from renal transplant recipients," Clinical Nephrology, vol. 52, no. 1, pp. 30-36, 1999.

[54] E.-S. Hwang and H. J. Lee, "Inhibitory effects of lycopene on the adhesion, invasion, and migration of SK-Hepl human hepatoma cells," Experimental Biology and Medicine, vol. 231, no. 3, pp. 322-327, 2006.

[55] B. Halliwell, "Oxidative stress in cell culture: an underappreciated problem?” FEBS Letters, vol. 540, no. 1-3, pp. 3-6, 2003.

[56] L. K. Henry, N. L. Puspitasari-Nienaber, M. Jaren-Galan, R. B. Van Breemen, G. L. Catignani, and S. J. Schwartz, "Effects of ozone and oxygen on the degradation of carotenoids in an aqueous model system," Journal of Agricultural and Food Chemistry, vol. 48, no. 10, pp. 5008-5013, 2000.

[57] P. Palozza, "Prooxidant actions of carotenoids in biologic systems," Nutrition Reviews, vol. 56, no. 9, pp. 257-265, 1998.

[58] C. S. Boon, D. J. McClements, J. Weiss, and E. A. Decker, "Role of iron and hydroperoxides in the degradation of lycopene in oil-in-water emulsions," Journal of Agricultural and Food Chemistry, vol. 57, no. 7, pp. 2993-2998, 2009.

[59] C. S. Boon, D. J. McClements, J. Weiss, and E. A. Decker, "Factors influencing the chemical stability of carotenoids in foods," Critical Reviews in Food Science and Nutrition, vol. 50, no. 6, pp. 515-532, 2010.

[60] D. B. Lovejoy and D. R. Richardson, "Iron chelators as antineoplastic agents: current developments and promise of the PIH class of chelators," Current Medicinal Chemistry, vol. 10, no. 12, pp. 1035-1049, 2003.

[61] M. Valko, C. J. Rhodes, J. Moncol, M. Izakovic, and M. Mazur, "Free radicals, metals and antioxidants in oxidative stressinduced cancer," Chemico-Biological Interactions, vol. 160, no. 1 , pp. 1-40, 2006.

[62] O. Livny, I. Kaplan, R. Reifen, S. Polak-Charcon, Z. Madar, and B. Schwartz, "Lycopene inhibits proliferation and enhances gapjunction communication of KB-1 human oral tumor cells," The Journal of Nutrition, vol. 132, no. 12, pp. 3754-3759, 2002. 
[63] M. A. Al-Mohanna, F. M. Al-Khodairy, Z. Krezolek, P.-A. Bertilsson, A. Al-Houssein, and A. Aboussekhra, "P53 is dispensable for UV-induced cell cycle arrest at late G1 in mammalian cells," Carcinogenesis, vol. 22, no. 4, pp. 573-578, 2001.

[64] S. Pavey, T. Russell, and B. Gabrielli, "G2 phase cell cycle arrest in human skin following UV irradiation," Oncogene, vol. 20, no. 43, pp. 6103-6110, 2001.

[65] T. Pötter, W. Göhde, N. Wedemeyer, and W. Köhnlein, "Keratinocytes exposed to ultraviolet radiation reveal three downregulated genes with potential function in differentiation and cell cycle control," Radiation Research, vol. 154, no. 2, pp. 151$158,2000$.

[66] A. Nahum, L. Zeller, M. Danilenko et al., "Lycopene inhibition of IGF-induced cancer cell growth depends on the level of cyclin D1," European Journal of Nutrition, vol. 45, no. 5, pp. 275-282, 2006.

[67] Y.-A. Choi, B. R. Chin, D. H. Rhee et al., "Methyl- $\beta$-cyclodextrin inhibits cell growth and cell cycle arrest via a prostaglandin $\mathrm{E}_{2}$ independent pathway," Experimental and Molecular Medicine, vol. 36, no. 1, pp. 78-84, 2004.

[68] A. R. Bowen, A. N. Hanks, S. M. Allen, A. Alexander, M. J. Diedrich, and D. Grossman, "Apoptosis regulators and responses in human melanocytic and keratinocytic cells," Journal of Investigative Dermatology, vol. 120, no. 1, pp. 48-55, 2003.

[69] D. Raj, D. E. Brash, and D. Grossman, "Keratinocyte apoptosis in epidermal development and disease," Journal of Investigative Dermatology, vol. 126, no. 2, pp. 243-257, 2006.

[70] V. Chaturvedi, P. Bacon, B. Bodner, and B. J. Nickoloff, "Proliferating cultured human keratinocytes are more susceptible to apoptosis compared with mouse keratinocytes," Journal of Investigative Dermatology, vol. 123, no. 6, pp. 1200-1203, 2004.

[71] R. Challa, A. Ahuja, J. Ali, and R. K. Khar, "Cyclodextrins in drug delivery: an updated review," AAPS PharmSciTech, vol. 6, no. 2, pp. E329-E357, 2005.

[72] A. Vyas, S. Saraf, and S. Saraf, "Cyclodextrin based novel drug delivery systems," Journal of Inclusion Phenomena and Macrocyclic Chemistry, vol. 62, no. 1-2, pp. 23-42, 2008.

[73] K. S. George, W. Elyassaki, Q. Wu, and S. Wu, "The role of cholesterol in UV light B-induced apoptosis," Photochemistry and Photobiology, vol. 88, no. 5, pp. 1191-1197, 2012.

[74] M. H. Aziz, H. T. Manoharan, and A. K. Verma, "Protein kinase $\mathrm{C} \varepsilon$, which sensitizes skin to sun's UV radiation-induced cutaneous damage and development of squamous cell carcinomas, associates with Stat3," Cancer Research, vol. 67, no. 3, pp. 13851394, 2007.

[75] T. Karlsson, A. Vahlquist, and H. Törmä, "Keratinocyte differentiation induced by calcium, phorbol ester or interferon$\gamma$ elicits distinct changes in the retinoid signalling pathways," Journal of Dermatological Science, vol. 57, no. 3, pp. 207-213, 2010.

[76] F. Afaq and H. Mukhtar, "Effects of solar radiation on cutaneous detoxification pathways," Journal of Photochemistry and Photobiology B: Biology, vol. 63, no. 1-3, pp. 61-69, 2001.

[77] A. B. Petersen, R. Gniadecki, J. Vicanova, T. Thorn, and H. C. Wulf, "Hydrogen peroxide is responsible for UVA-induced DNA damage measured by alkaline comet assay in $\mathrm{HaCaT}$ keratinocytes," Journal of Photochemistry and Photobiology B: Biology, vol. 59, no. 1-3, pp. 123-131, 2000.

[78] H. Sies and C. F. M. Menck, "Singlet oxygen induced DNA damage," Mutation Research DNAging, vol. 275, no. 3-6, pp. 367-375, 1992.
[79] S. Onoue, Y. Seto, A. Oishi, and S. Yamada, "Novel methodology for predicting photogenotoxic risk of pharmaceutical substances based on reactive oxygen species (ROS) and DNAbinding assay," Journal of Pharmaceutical Sciences, vol. 98, no. 10, pp. 3647-3658, 2009.

[80] B. Harang, Composition Having Tanning and Photoprotective Activity, and Its Cosmetic Applications, Laboratoire Oenobiol, 2000.

[81] A. Nagao, "Oxidative conversion of carotenoids to retinoids and other products," Journal of Nutrition, vol. 134, no. 1, pp. 237S240S, 2004.

[82] H. L. Hantz, L. F. Young, and K. R. Martin, "Physiologically attainable concentrations of lycopene induce mitochondrial apoptosis in LNCaP human prostate cancer cells," Experimental Biology and Medicine, vol. 230, no. 3, pp. 171-179, 2005.

[83] A. D. Rhim and A. K. Rustgi, "Three-dimensional organotypic culture of stratified epithelia," Cold Spring Harbor Protocols, vol. 2015, no. 4, pp. 349-353, 2015.

[84] A. Acheva, M. Ghita, G. Patel, K. M. Prise, and G. Schettino, "Mechanisms of DNA damage response to targeted irradiation in organotypic 3D skin cultures," PLoS ONE, vol. 9, no. 2, Article ID e86092, 2014.

[85] H. Vörsmann, F. Groeber, H. Walles et al., "Development of a human three-dimensional organotypic skin-melanoma spheroid model for in vitro drug testing," Cell Death and Disease, vol. 4, no. 7, article e719, 2013. 


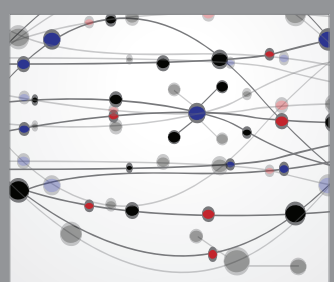

The Scientific World Journal
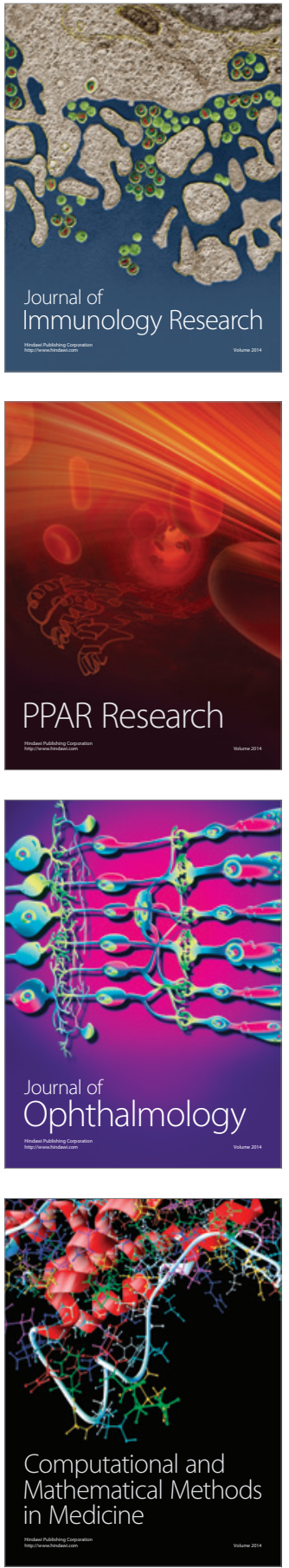

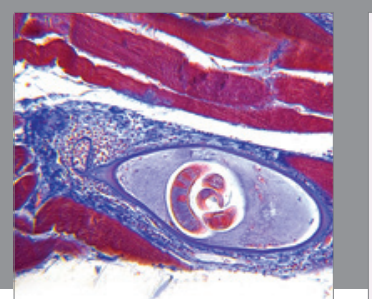

Gastroenterology Research and Practice

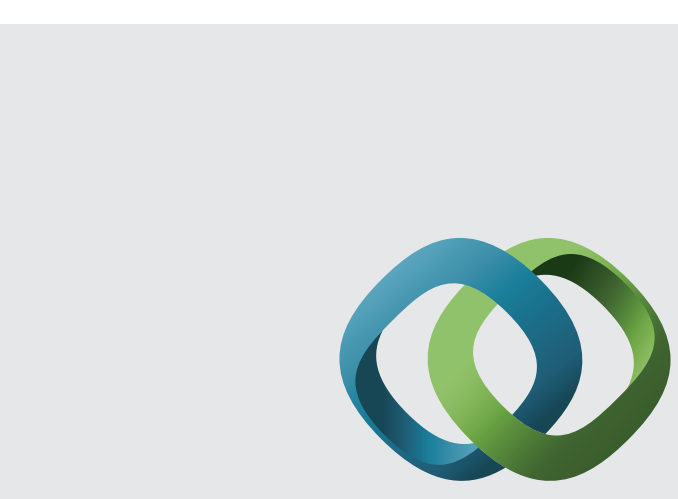

\section{Hindawi}

Submit your manuscripts at

http://www.hindawi.com
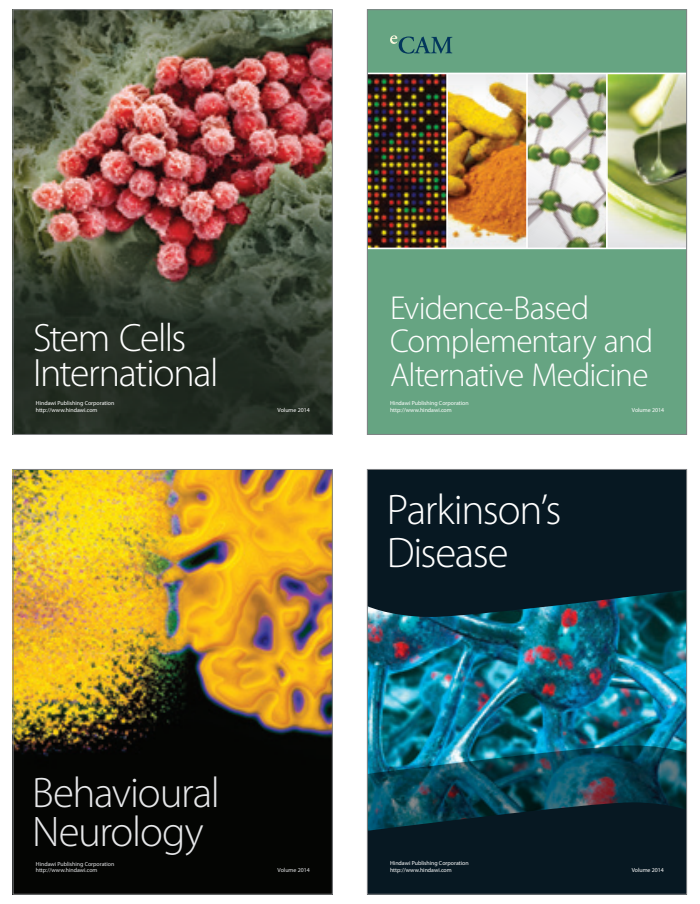
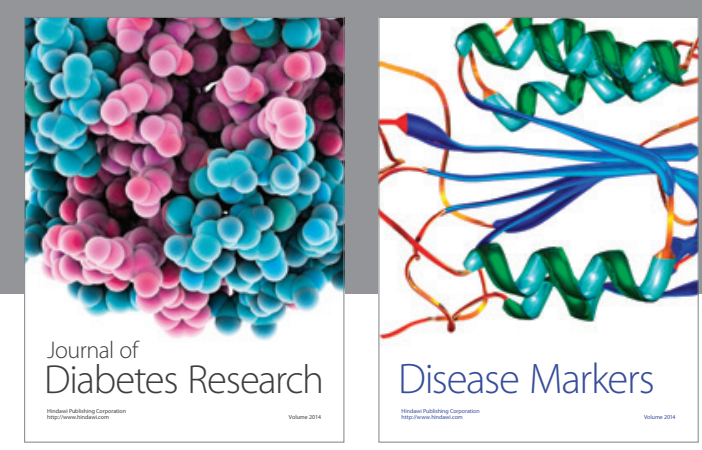

Disease Markers
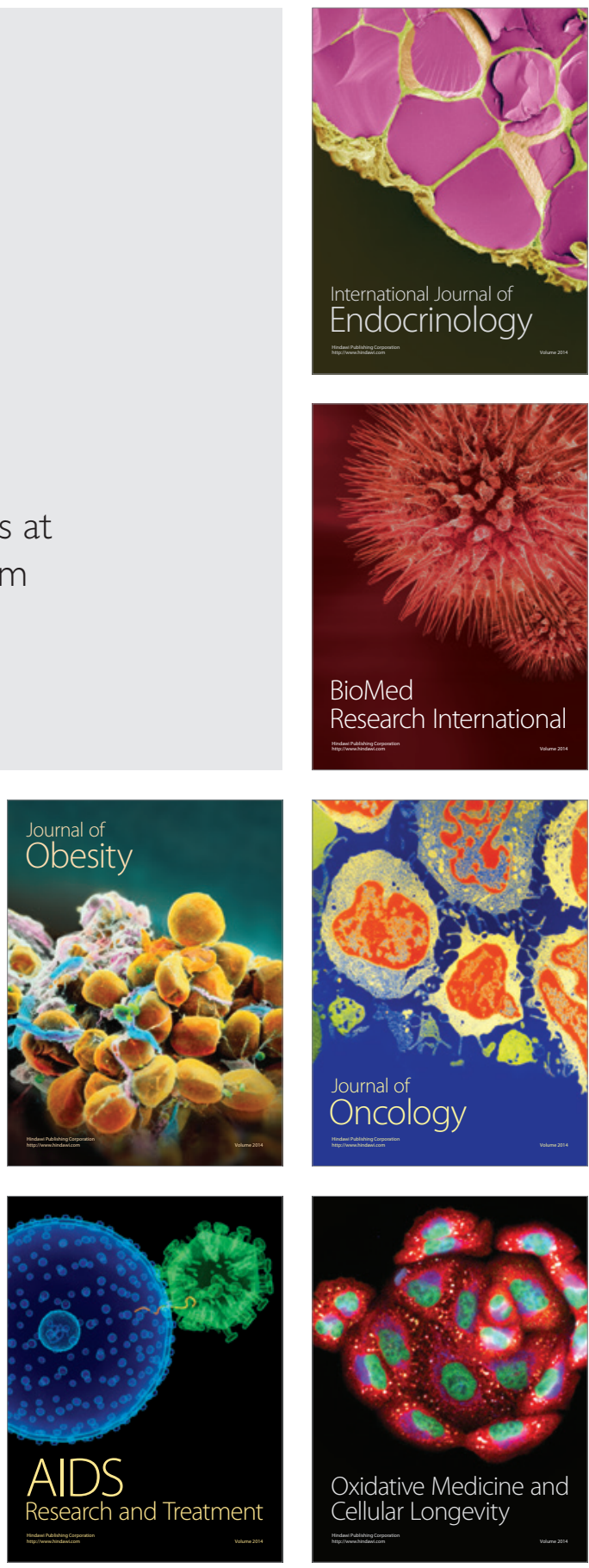